\title{
REVIEW
}

\section{Ontogenetic and Phylogenetic Development of the Endocrine Pancreas (Islet Organ) in Fishes}

\author{
John H. Youson and Azza A. Al-Mahrouki \\ Department of Zoology and Division of Life Sciences, U niversity of Toronto at Scarborough, \\ Scarborough, Ontario M 1C 1A4 Canada
}

Accepted August 25, 1999

The morphology of the gastroenteropancreatic (GEP) system of fishes was reviewed with the objective of providing the phylogenetic and ontogenetic development of the system in this vertebrate group, which includes agnathans and gnathostome cartilaginous, actinoptyerygian, and sarcopterygian fishes. Particular emphasis is placed on the fish homolog of the endocrine pancreas of other vertebrates, which is referred to as the islet organ. The one-hormone islet organ (B cells) of larval lampreys is the most basic pattern seen among a free-living vertebrate, with the two-hormone islet organ ( $B$ and $D$ cells) of hagfish and the three-hormone islet organ (B, D, and $F$ cells) of adult lampreys implying a phylogenetic trend toward the classic four-hormone islet tissue (B, D, $F$, and A cells) in most other fishes. An earlier stage in the development of this phylogenetic sequence in vertebrates may have been the restriction of islet-type hormones to the alimentary canal, like that seen in protochordates. The relationship of the islet organ to exocrine pancreatic tissue, or its equivalent, is variable among bony, cartilaginous, and agnathan fishes and is likely a manifestation of the early divergence of these piscine groups. Variations in pancreatic morphology between individuals of subgroups within both the lamprey and chondrichthyan taxa are consistent with their evolutionary distance. A comparison of the distribution and degree of concentration of the components of the islet organ among teleosts indicates a diffuse distribution of relatively small islets in the generalized euteleosts and the tendency for the concentration into Brockmann bodies of large (principal) islets (with or without secondary islets) in the more derived forms. The holostean actinopterygians (Amiiformes and Semiontiformes) share with the basal teleosts (osteoglossomorphs, elopomorphs) the diffuse arrangement of the components of the islet organ that is seen in generalized euteleosts. Since principal islets are also present in adult lampreys the question arises whether principal islets are a derived or a generalized feature among teleosts. There is a paucity of studies on the ontogeny of the GEP system in fish but it has been noted that the timing of the appearance of the islet cell types parallels the time that they appear during phylogeny; the theory of recapitulation has been revisited. It is stressed that the lamprey life cycle provides a good opportunity for studying the development of the GEP system. There are now several markers of cell differentiation in the mammalian endocrine pancreas which would be useful for investigating the development of the islet organ and cells of the remaining GEP system in fish. 1999 Academic Press

Scientific interest in the distribution, structure, and function of endocrine tissues associated with the alimentary canal (gastroenteropancreatic, GEP, system) of fishes can be traced back at least to the beginning of the 19th century. This interest has heightened as we 
approach the end of the 20th century. Thus, through nearly 200 years of investigation there is still a dual fascination with the importance of the GEP tissue to individual fish species and to how the tissue in fishes in general relates to that found in higher vertebrates (Falkmer, 1995). With commercially valuable species, knowledge of this tissue is essential, for hormones elaborated by the GEP system are critical in intermediary metabolism, which in turn is crucial for fish growth and eventual maturity (Plisetskaya, 1990a,b); some GEP hormones have direct effects even on these latter two parameters (Plisetskaya and Mommsen, 1996). Since the hormones of the GEP system have equally important roles in higher vertebrates, including humans, the origins of the cells of the GEP system in the context of where and how they develop (ontogenesis) and when they appeared during the history of vertebrates (phylogenesis) have been continuous curiosities (Bonner-Weir and Weir, 1979; Epple and Brinn, 1986, 1987). With the refinement of techniques to isolate and sequence peptides or to clone cDNAs, the past 2 decades have seen an explosion in the information on the molecular structure of fish GEP peptides. The primary structures of these peptides in fishes have been crucial for analyses which attempt to explain the molecular evolution of GEP peptides of vertebrates (e.g., Conlon, 1995; Larhammar, 1996; Plisetskaya and Mommsen, 1996). The bioactivity of isolated peptides from fishes, relative to that of higher animals, has provided examples of both a suspected modern specialization and a regression of function of GEP hormones (Falkmer, 1995).

The above paragraph emphasizes the value that can be placed on investigations into the GEP system of fishes. This view is certainly not novel, for many well-known comparative endocrinologists have illustrated this point in extensive, earlier reviews (Epple, 1969; Epple and Lewis, 1973; Epple and Brinn, 1986, 1987; Falkmer, 1985a,b, 1995; Plisetskaya, 1989a,b, $1990 a, b)$. In many ways, this review is dedicated to these pioneers and some of their views will be reexamined and placed in the context of more recent literature. It is the objective of this report to provide an update of the literature on the GEP system as it pertains to the topics of ontogeny and phylogeny of this system in fish. As it will soon be demonstrated, it is difficult to separate the endocrine cells within the alimentary canal (stomach and intestine) with cells of similar type, or elaborating similar hormones, in the endocrine pancreas. The endocrine cells of these three components have an intimate ontogenetic history. However, the primary focus of this update will be on the fish homolog of the endocrine pancreas present in nonpiscine vertebrates. Furthermore, the focus will be a comparison of the distribution, structure, and ontogeny of the endocrine pancreatic tissue through the various groups of fishes, rather than on the comparative function and structure of the peptides that they generate.

\section{DEFINITION OF TERMS}

Ontogeny is development of a single individual, or a system within the individual, from the fertilized egg to death (Smith, 1960), i.e., a total life history including embryonic and postnatal (Gould, 1977). This term should be distinguished from phylogeny, which is a type of development involving modification of a species or a group of species, i.e., "the family history" or the evolutionary history of a lineage (Gould, 1977). This latter type of development is characterized by accompanying changes in structure and function (Smith, 1960). It is the evolutionary trend, or morphocline (Hildebrand, 1995), of the GEP system of fishes, a particular phyletic line, that is being considered in this review. The word fish has different connotations so it is important to establish the terms of reference for this review. The interpretation of Nelson (1994) is adopted, that is, the term "fish" includes both the jawless (Agnatha) and the jawed (Gnathostomata) aquatic vertebrates that "... have gills throughout life and limbs, if any, in the form of fins." This broad definition includes the agnathans, the hagfishes and lampreys, and the two large extant grades of aquatic gnathostome fishes, Chondrichthimorphi and Teleostomi. The former grade consists of the class Chondrichthyes, which possesses the subclasses Holocephali (single order Chimaeriformes) and Elasmobranchi (containing many orders under superorder Euselachii). Grade Teleostomi contains the classes Sarcopterygii (lobefinned fishes) and Actinopterygii (ray-finned fishes). It is the former, and certainly not the latter, class which lead to the tetrapods. Thus in the context of vertebrate 
evolution, the actinopterygians, and particularly the teleosts, are a highly specialized group which some might consider led to a dead end. Among the piscine groups are one-half the approximately 50,000 species of living vertebrates and these fishes demonstrate tremendous diversity in their form and distribution. Needless to say, this report cannot take advantage of this diversity and likely will be concerned with only fewer than $1.0 \%$ of the living fishes. Despite this, attempts will be made to provide data on examples from as many of the 57 orders of fishes as possible. However, since a central theme of this review is phylogenetic development and the authors have a prime interest in fishes of ancient lineage, particular regard will be given to some of the more ancient orders. The term primitive is used rather sparingly because it implies a lack of specialization and some of the ancient members to be discussed are highly specialized, despite their ancient origins. As seems to be the practice among fish taxonomists of the day, the terms lower, basal, and generalized reflect close to the starting place of a character or a group and derived implies a character or a group that has been taken from another (earlier) source. The term gastroenteropancreatic (GEP) system is of common use and it has already been employed above in the Introduction to emphasize a system of endocrine cells involving the stomach, intestine, and pancreas. The term enteropancreatic (EP) system has recently been applied to the endocrine cells of the intestine and pancreas of lampreys and hagfish, for both of the these agnathans lack a stomach (Youson, 1999). The EP system would seem more appropriate for other fishes without a stomach (see: NoaillacDepeyre and Hollande, 1981; Rombout and TaverneThiele, 1982).

GEP and EP are considered by some not to be all-inclusive terms. Some of the peptides secreted by cells of the GEP system are also secreted by cells of the central nervous system. In fact, Falkmer and his colleagues have continuously emphasized the developmental relationship between the cells of these two systems; collectively they are part of a diffuse neuroendocrine system (Falkmer, 1985a,b, 1995). To emphasize this relationship and their common synthetic capacity, the acronym APUD cells, for amine precursor uptake and decarboxylation, has been used for some of the cells of these two systems (Pearse, 1969). With the application of antisera and immunohistochemistry in the investigations of endocrine cells of the stomach, intestine, and pancreas of fishes, the use of words such as argentaffin, argyrophilic, and enterochromaffin is gradually disappearing. However, techniques which identify any one of these three features in cells are still valuable in the identity of putative endocrine cells which show no immunoreactivity to antisera against recognized peptides.

The endocrine pancreatic homolog in fishes is referred to as the endocrine pancreas, islet tissue, insular tissue, islet or insular organ, islets of Langerhans, Brockmann bodies, and principal islets. It is surmised from reading previous reviews that the term islet organ is the endocrine pancreatic homolog of a species, irrespective of its distribution or arrangement, i.e., whether the islets which make up the organ are large or small and whether they are concentrated or disseminated (Epple and Brinn, 1986, 1987; Falkmer, 1995). Recently, principal islet has been defined as the largest accumulation of endocrine tissue in the fish pancreas, surrounded by a thin rim of exocrine tissue (Plisetskaya and Mommsen, 1996). Epple and Brinn (1986, 1987) have defined Brockmann bodies as large accumulations of islet tissue (principal islets) closely associated with exocrine pancreatic tissue. However, more commonly, Brockmann bodies and principal islets are used as synonyms in reference to large bodies of pure islet tissue devoid of, or nearly devoid of, strands of exocrine pancreas (Falkmer and Patent, 1972; Falkmer and Van Noorden, 1983; Falkmer, 1985a,b, 1995; Yang and Wright, 1995; Maglio and Putti, 1998). The "Brockmann body regions" from species such as tilapia (Oreochromis niloticus) are under investigation as a source of islet tissue for human transplant because of the compacted and pure nature of the "region" (Yang and Wright, 1995). In a pure sense, in tilapia the "region" is a Brockmann body or several Brockmann bodies and each is composed of some principal islets (large islets). The Brockmann body(ies) and other islet tissue, if present, makes up the islet organ for this species. For the purposes of this review, and perhaps for future use, principal islet and Brockmann body are synonyms if the Brockmann body contains a single principal islet. Otherwise, a Brockmann body is a concentration of pancreatic islets among the viscera of fish. 


\section{PHYLOGENY OF THE FISH GEP SYSTEM}

\section{General M orphology of the Teleost Islet Organ}

A baseline description of the islet organ in a representative fish species is an essential requirement for the discussion of the topic of ontogeny and phylogeny of fishes. The species we have chosen is a teleost, the white sucker (Catastomus commersoni), and to our knowledge there has not been a detailed description of its GEP system. McCormick (1925) provided only a brief description of this species in his monograph.

Teleostei is a division of the subclass Neopterygii among actinopterygians. Recent Teleostei are believed to be monophyletic and the division consists of the small subdivisions Osteoglossomorpha, Elopomorpha, and Clupeomorpha and the large subdivision Euteleostei (De Pinna, 1996). The white sucker is a member of the order Cypriniformes and of the superorder Ostariophysi within the largest subdivision (Euteleostei) of teleosts (also see below for alternate classification of ostarioiphysians). Cyprinids rank second only to the order Perciformes in total number of species; there are 2662 species of cyprinids, all of which are freshwater (Nelson, 1994). Epple and Brinn (1975) give only brief reference to the distribution of the exocrine pancreas and the islet size in two species of Cypriniformes. More extensive reports of the islet tissue of cyprinids are those on carp and goldfish (Kobayashi and Takahashi, 1970; Nakamura and Yokote, 1971; Rombout et al., 1979; Rombout and TaverneThiele, 1982).

Epple and Brinn (1975) described five morphological relationships between the exocrine and endocrine pancreatic tissues (islet organ) of vertebrates and among these was the actinopyterygian ("ray-finned fishes") type (Fig. 1), which includes most bony fishes, such as the sucker. As might be expected for this large group of fishes, there is great structural diversity in the islet organs but species share the common feature of a diffuse exocrine pancreas of serous acini within the mesentery extending between bile ducts, abdominal blood vessels, the gastrointestinal tract, the gall bladder, and the liver. Intrahepatic concentrations of exocrine tissue are common among the teleosts (Epple and Brinn, 1986). The islet tissue can be found anywhere within these areas, except in intrahepatic sites, but is most commonly concentrated near where the extrahepatic common bile duct enters the intestine at the junction of the stomach, intestine, and intestinal caeca. This association of the islet tissue with extrahepatic bile ducts in teleosts is noteworthy and will be referenced at a later point in this review, for there is both ontogenetic and phylogenetic significance.

The islet tissue is in the form of highly vascularized collections of epithelial cells, usually separated from the exocrine acini by a small amount of fibrous connective tissue but generally not confined within a true capsule (Fig. 2a). The epithelial aggregates (islets) stain lightly with hematoxylin and eosin compared to the acinar cells, which have large acidophilic granules. The islets are of variable size but the cells are arranged as cords or small lobules. In the white sucker, islets were aggregated near the gall bladder and some were of considerable size, i.e., principal islets, but among small strands of exocrine acini and pancreatic ducts and other smaller (secondary) islets. One principal islet, visible to the naked eye, was located within a concavity of the liver and was surrounded by only a narrow rim of exocrine acini (Fig. 2a). The term Brockmann body can be used for both this isolated principal islet and the larger mass of islet tissue located more posteriorly. All islets of the white sucker immunostain for insulin using anti-mammalian insulin serum, but the immunoreaction of these B cells was weak compared to that of positive controls. The $\mathrm{B}$ cells and D cells (immunoreactive with anti-somatostatin-25) were distributed throughout the islet. A cells were immunoreactive with anti-glucagon and were primarily localized in the periphery of islets, but with smaller numbers scattered throughout more central regions (Fig. 2b). F cells (immunoreactive with anti-PYY) were noted in the same peripheral locations as some of the A cells.

\section{Comparative Morphology of the Euteleost Islet Organ}

There have been many studies of the structure of the GEP system in euteleosts. The reader is referred to the extensive series of reports on GEP cells of the stomach, intestine, and islet tissue of the sea bass, Dicentrarchus labrax (Carrillo et al., 1986; Beccaria et al., 1990; Lozano et al., 1991a,b; Agulleiro et al., 1993; Gomez-Viscus et al., 1996, 1998), and the gilt-head sea bream, Sparus aurata (Abad et al., 1986, 1987, 1988, 1992; Elbal et al., 1991), where reviews of earlier literature are provided. It is 


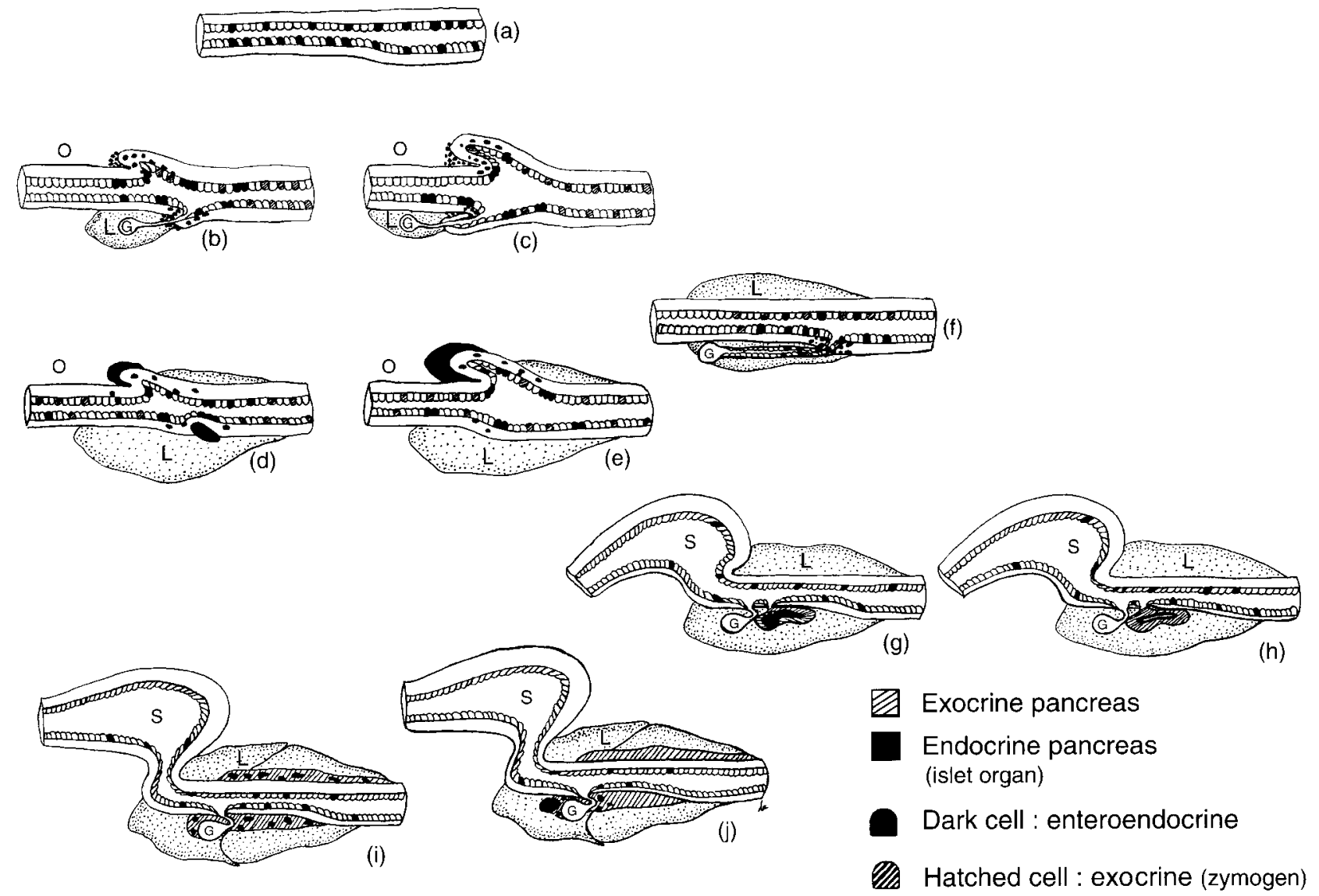

FIG. 1. Diagrammatic representation of the distribution of the endocrine tissue (islet organ) in fishes relative to the exocrine pancreatic tissue, esophagus (O), stomach (S), intestine (unlabeled portion of gut), liver (L), gall bladder (G), and bile duct (tube leading from the gall bladder). The epithelial cells of the digestive tube are enlarged relative to the cells of other structures to denote the presence of endocrine (dark) and exocrine (hatched) cells. Represented are a protochordate (a), a larval lamprey: Northern Hemisphere (b), a larval lamprey: Southern Hemisphere (c), an adult lamprey: Northern Hemisphere (d), an adult lamprey: Southern Hemisphere (e), a hagfish (f), an holocephalian (g), an elasmobranch (h), a basal actinopterygian (i), and a derived euteleost (j). The protochordate has no pancreas but enteroendocrine cells and larval and adult lampreys and the hagfish have exocrine and endocrine cells in the intestine. The islet organ is seen as scattered follicles at the esophagus-intestinal junction in larvae and around the bile duct-intestinal junction in the hagfish. Islet organs are one (e) or two (d) principal islets in adult lampreys. The exocrine tissue and islet organs are intermingled in the remaining species, with a compact organ in the two cartilaginous fishes ( $\mathrm{g}$, $\mathrm{h}$ ) and a more diffuse organ in the two bony fishes $(i, j)$; islets are small and diffuse in i but more concentrated (Brockmann body) and with a cranial principal islet in $\mathrm{j}$.

important to highlight several other earlier morphological studies of islet tissue from euteleosts, for they are associated with the isolation of peptides and the production of antisera which greatly influenced subsequent directions of research on regulatory peptides in fish. These are investigations of islet tissue in salmonids (Wang et al., 1986; Nozaki et al., 1988a,b) and in the anglerfish, Lophius americanus (Johnson et al., 1976).

The most extensive comparative analysis of the islet organ of euteleosts is undoubtedly that of McCormick (1925), a member of the Department of Physiology, University of Toronto, during the time that insulin was discovered in this department. He examined the position, size, and number of islets and the extent of invasion by acinar tissue and connective tissue in 70 species of what today would be classified as euteleosts (Nelson, 1994). McCormick (1925) noted that the islet tissue among the species was of variable types, which he attempted to relate to the fish taxonomy of the day. 

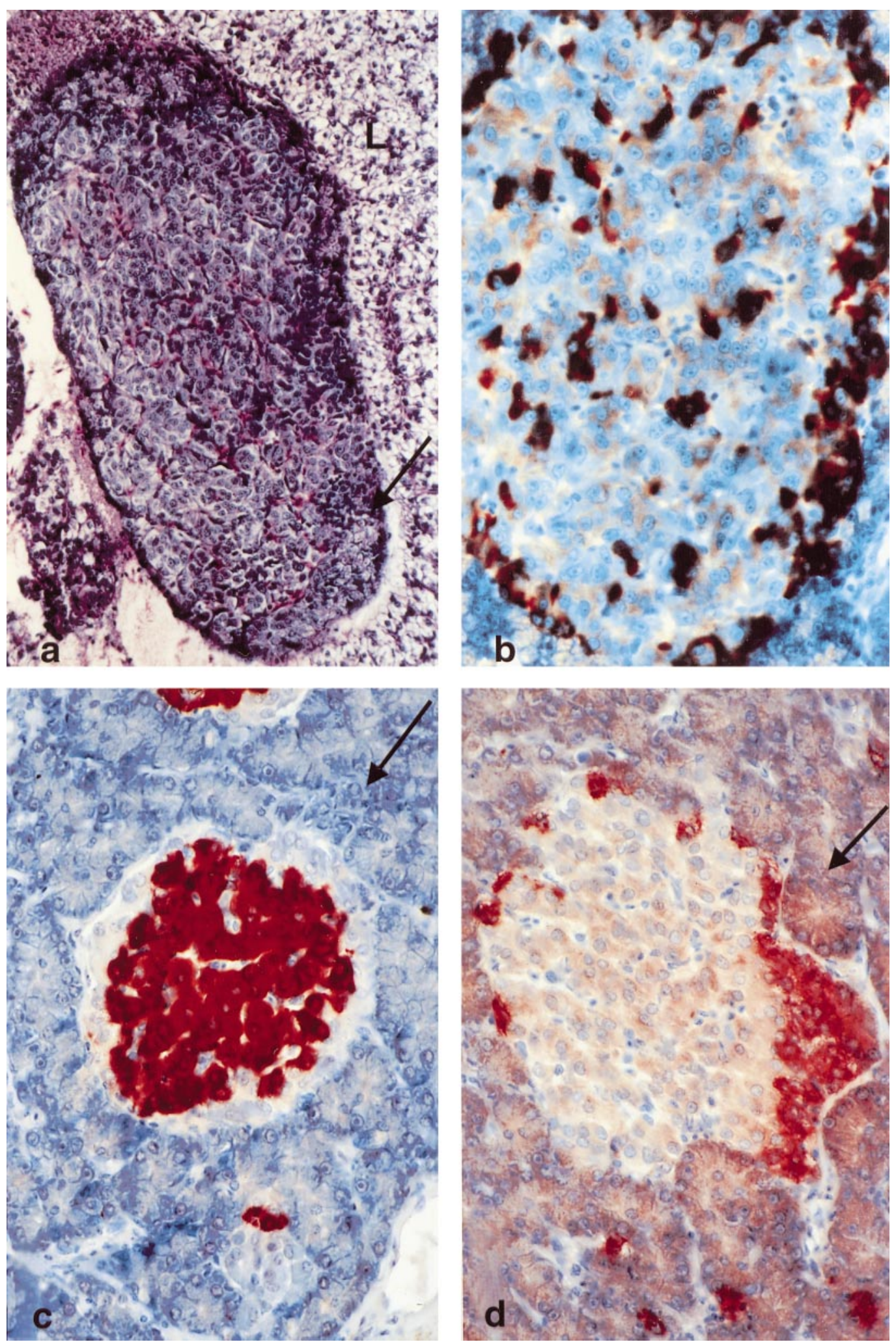
His general conclusion was that the Lophobranchii (Series Percomorpha, Order Gasterosteiformes, Family Syngnathidae:pipefishes) showed the first principal islet which was free from acinar tissue. He considered this to be an advanced feature, for most of the "earlier orders" had an "intermediate type," where islets were of variable size among extensive exocrine tissue. Since he also noted consistencies of structure within common groups of teleosts, McCormick (1925) implied that there may be some relationship between the morphology of islet tissue and the taxonomic position. This study of nearly 75 years ago also examined the islet tissue of more basal teleosts and nonteleost actinopterygians and thus can be considered the first investigation of the phylogenetic development of the fish islet organ. Subsequent to the report of McCormick (1925), there was a study of equal magnitude by Siwe (1926) and then many reviews appeared (e.g., Epple, 1969; Falkmer and Patent, 1972; Epple and Brinn, 1975, 1986, 1987; Falkmer, 1985a,b, 1995) where phylogenetic development of fish islet tissue was considered in the wider context of the vertebrate endocrine pancreas. The question arises whether we now have sufficient data to provide a clear picture of whether the comparative morphology of the islet organ of euteleosts reflects any phylogenetic development of this system?

There are 32 orders of euteleosts and many have numerous suborders, superfamilies, families, subfamilies, genera, and subgenera (Nelson, 1994). A review of the literature since McCormick (1925) indicates that the islet tissue has been examined in representatives of only 14 of these 32 orders and 24 of the 391 families. These are Batrachoidiformes (family Batrachoidae, toadfishes), Characiformes (family Characidae, tetras), Cyprinodontiformes (families Fundulidae and Poeciliidae, killifishes and poecilids, respectively), Cypriniformes (families Cyprinidae and Gyrinocheilidae, cyprinids and algae eaters, respectively), Esociformes (family Esocidae, pikes), Gadiformes (family Gadidae, cods), Lophiformes (family Lophiidae, goosefishes), Mugiliformes (family Mugilidae, mullets), Perciformes (families Blenniidae, Cichlidae, Gobiidae, Helostomatodae, Moronidae, and Sparidae), Pleuronectiformes (family Pleuronectidae, flounders), Salmoniformes (family Salmonidae, salmonids), Scorpaeniformes (families Scorpaenidae and Cottidae, rockfishes and sculpins, respectively), Siluriformes (families Callilchthyidae, Heteropneustidae and Ictaluridae, catfishes), and Tetradontiformes (family Tetradontidae, puffers). This sample represents just a token of the 22, 262 euteleostean species, which have highly divergent habits and ancestral origins (Nelson, 1994). Therefore, one would expect that little could be achieved in terms of phylogenetic patterns in islet tissue through comparisons of so few species. However, it is noteworthy that, without design, the species that have been studied are in superorders that are often referenced as more generalized (Ostariophysi, Protacanthopterygii) and more derived (Paracanthopterygii, Acanthopterygii) euteleosts; the latter are two of the seven superorders which are considered neoteleosts. Nevertheless, sampling of the islet organs in euteleosts has favored the derived orders (8) as opposed to those that are considered more generalized (5). Furthermore, it should be mentioned that an alternate view is that orders of Ostariophysi mentioned above, namely, Characiformes, Cypriniformes, and Siluriformes, are not part of the euteleostean subdivision but instead are more related to the subdivision Clupeomorpha, lower on the teleostean taxonomic scale (Lecointre and Nelson, 1996). Thus if these three are removed from the euteleosts, then only the Esociformes and Salmoniformes are left to represent characteristics of the islet organ of the generalized euteleosteans.

The small sample size is just one of many limitations of comparing morphological features of the islet tissue among generalized and derived euteleosts using existing data. Two other major limitations are the selection

FIG. 2. Islet tissue among exocrine acini (arrows). (a) A principal islet in a Brockmann body of the white sucker, Catastomus commersoni, is surrounded by a narrow rim of exocrine acini and is located within a concavity of the liver (L). Stain: hematoxylin-eosin; original magnification; $\times 150$. (b) Portion of a large islet from the white sucker showing immunoreactivity of A cells to anti-glucagon sera; original magnification; $\times 300$. (c) A small islet among exocrine acini from the bowfin, Amia calva, shows a central aggregate of B cells immunoreactive with anti-mammalian insulin; original magnification; $\times 300$. (d) Intermediate-sized islet from the bowfin Amia calva showing peripheral F cells immunoreactive with anti-mammalian NPY; original magnification; $\times 300$. Sections in b, c, and d were immunolabeled using rabbit histostain-SP kit $($ Zymed-Lab-SA System, San Francisco, CA). Positive staining is indicated by red coloration and the counterstain is hematoxylin. 
of suitable parameters for comparison and the fact that one has to assume that there is consistency among investigations in both the type and the thoroughness of the observations. The types of observations are quite variable in recent publications of the GEP cells in euteleosts. Needless to say, all three are highly relevant limitations and there is a need for an investigation where these variables are eliminated. Given these inherent problems, are there any morphological parameters that can be used? The following are parameters that could be used in a thorough comparison of the GEP system among several groups of euteleosts: distribution of islets; size variation of islets; presence or absence of principal islets; degree of islet-acinar association; the number of cell types in the islet; distribution of cell types within the islet; and the presence/ absence and distribution of specific immunoreactive cell types in the gastrointestinal system, e.g., somatostatin or insulin. At the transmission electron microscopic level, one could compare among species granule shape and density and the presence/absence of colocalization of peptides within designated cell types but these morphological parameters have proved to be inconsistent even among closely related fishes (Brinn, 1973).

The point to be emphasized is that under the present circumstances it is not possible to come to any definitive conclusions about the phylogenetic development of the endocrine pancreatic homolog (islet organ), and the GEP system in general, within the euteleosts. Having stated this, are there any suggested trends in the phylogenetic development of the GEP system in euteleosts? Langer et al. (1979) concluded from their immunohistochemical study of the gastrointestinal system of 11 species of teleosts that since there is so much variation in immunoreactivity that caution should be exercised in generalizing about peptide distribution. This opinion had been expressed much earlier (Falkmer and Patent, 1972). The more recent example of anti-insulin immunoreactivity of cells in the stomach of the sea bass, a derived euteleost, is support for this variation, which may have no relation to phylogenetic development (Gomez-Visus et al., 1996). In contrast, an examination of the distribution of islet tissue among the euteleosts seems to show some phylogenetic relatedness (Epple and Brinn, 1986).

McCormick (1925, p. 78) stated in relation to fish islet morphology that, "In the gross there is some evident relationship to the accepted classification of fishes." The more derived euteleosts, which Epple and Brinn (1975) reference as Ctenosquamata, have a substantial aggregation of islet tissue in extrapancreatic Brockmann bodies. The phylogenetic development of islet tissue seems to be toward at least a single, large principal islet (in this case also called a Brockmann body) independent or nearly independent of exocrine elements and located near the gall bladder or spleen. Examples of this arrangement are present in the derived orders Cyprinodontiformes, Lophiformes, and Scorpaeniformes (Boquist and Patent, 1971; Johnson et al., 1976; Klein and Lange, 1977; Patent et al., 1978; Klein and Van Noorden, 1980; Stefan and Falkmer, 1980). Other derived orders have a single principal islet (Brockmann body) with limited exocrine tissue associated but also several intermediate and smallsized islets among the exocrine acini (Fig. 1j). These include Mugiliformes, Perciformes, and Tetradontiformes (Kobayashi et al., 1976; Abad et al., 1986; Lozano et al., 1991a,b; Maglio and Putti, 1998). It is noteworthy, and perhaps not unexpected, that Fundulus varied from another cyprinodontiform (Xiphophorus) in having this second type of arrangement (Epple and Brinn, 1975). This illustrates that inevitably, some intraorder variation will exist.

An intermediate step in the phylogenetic development of the euteleost principal islet may be found within order Salmoniformes. In both rainbow trout and coho salmon there is not a principal islet but pancreatic islets, some of the size of principal islets, aggregated in a mass (a Brockmann body?) alongside the gall bladder and surrounded by exocrine acini (Wagner and McKeown, 1981; Wang et al., 1986; Nozaki et al., 1988a,b). Islets are also diffusely distributed in the adipose tissue that surrounds the pyloric caeca and the spleen. The mass of islets is called an islet organ (Wagner and McKeown, 1981) or principal body (Wang et al., 1986), with the former described in the trout as consisting of many islets that fused together with a surrounding capsule of exocrine pancreatic tissue. Wagner and McKeown (1981) noted that in small trout the mass is more compact and surrounded by exocrine acini, but in larger fish exocrine tissue invaded the mass and divided it into small groups of islets. It is not difficult to visualize this arrangement as eventually being replaced in more derived euteleosts by a com- 
pact islet organ of a principal islet(s), i.e., a Brockmann body, nearly or totally devoid of exocrine elements. Other orders, such as Cypriniformes and Siluriformes, provide some support for a more basal arrangement of islet tissue in the more generalized euteleosts, i.e., a more diffuse arrangement of islet tissue in the islet organ. In the cyprinid Carassius, numerous welldefined islets of varying size are scattered throughout the exocrine pancreas. However, macroscopically visible islets (principal islets?) are also found in the mesentery (Kobayashi and Takahashi, 1970). Moreover, in Barbus conchonius a principal islet is located between the gall bladder and the intestinal bulb, and there are many small islets more caudally (Rombout et al., 1979). This description would also fit the islet organ of the white sucker described herein. Although the silurids (catfishes) have been described as having a principal islet located close to the gallbladder (Brinn, 1975; Johnson et al., 1976), they are referenced by Epple and Brinn (1975) as having an intermediate islet distribution like the cyprinids, that is, also extensive smaller islets within the exocrine pancreas. In these groups, although there may be some large islets which one may wish to refer to as principal islets, they do not all possess a Brockmann body.

The distribution of the four principal cell types (A, B, D, F) within the islets of euteleosts has been described in many species. The most consistent pattern is a central core of B cells, a diffuse arrangement of D cells, and A and F cells at the periphery of each islet. It is noteworthy that the white sucker showed a broad distribution of the anti-glucagon immunoreactive A cells (Fig. 2b). The distribution of D cells has particular relevance to their modulation of $\mathrm{A}$ and $\mathrm{B}$ cell secretion (Maglio and Putti, 1998). Two types of D cells, D1 and D2, are present in islets of many euteleosts and they have a specific distribution and a specific immunoreactivity to various types of somatostatin antisera (Nozaki et al., 1988a; Abad et al., 1992).

\section{Endocrine Pancreas of Lower Teleostei}

For further analysis of the possible existence of some phylogenetic pattern of islet distribution and arrangement among teleosts it is possible to include data from two of the three other subdivisions: Osteoglossomorpha, Elopomorpha, and Clupeomorpha. To our knowl- edge there is no collective name for these three subdivisions of Teleostei but they are generally accepted as being the most generalized or low on the taxonomic scale of teleosts. Among the Elopomorpha is the order Anguilliformes, which includes the eels. The pancreas of the eel is compact and has been described as tetrapod-like in also having islets scattered throughout. The general view is that eels do not have principal islets or aggregates of islets (Brockmann bodies) like those of more derived teleosts (Kobayashi and Takahashi, 1974; Epple and Brinn, 1975). However, in addition to scattered small islets in the head and tail of the pancreas, L'Hermite et al. (1985) describe in the middle of the pancreas two voluminous islets in leptocephali and a single islet, which they call the Brockmann body, in the glass eel and in the adult stages. These latter data imply that there is a principal islet in adult eel and that it is formed during metamorphosis from the fusion of two smaller principal islets. Furthermore, large islets become more conspicuous in the pancreas of adult Anguilla rostrata during lipopexia (A. Epple, personal communication). Thus there is some controversy about the structure of the islet organ in eels; however, the general consensus is that islet tissue is not organized into Brockmann bodies.

The scattered distribution of islets of variable size without any large islet masses (i.e., a Brockmann body) is well documented in one of the most basal of extant teleosts, the Osteoglossomorpha (bonytongues). The distribution of this geologically ancient and monophylectic teleost group was likely influenced by shifts in tectonic plates after the Jurassic period and today members are found on most continents ( $\mathrm{Li}$ and Wilson, 1996). In general, the distribution of islet tissue in the islet organ of osteoglossomorphs (Al-Mahrouki and Youson, 1998) is reflective of their basal position among the teleosts, that is, no distinct aggregation of islets but a diffuse dissemination of islet tissue among exocrine acini (Fig. 1i). This recent study serves as an example of how morphological features, such as distribution and arrangement of islet tissue and types and distribution of gut endocrine cells, can be of some value in taxonomic characterization even within groups. There were similarities in islet distribution and arrangement in species within and between families and distinct differences between orders and suborders (Al-Mahrouki and Youson, 1998). One species, Pantodon, 
which is the most distant of the five species studied, showed the most extreme variation in islet distribution. This species also showed anti-insulin immunoreactivity in both the stomach and intestine, whereas others had either no immunoreactivity in either organ or immunoreactivity in only the intestine. It was concluded that variations in the GEP system of extant osteoglossomorphs may reflect more divergent evolutionary histories among species than is presently believed and/or that interspecific differences are a consequence of variations in ontogeny of cells of the system.

\section{Islet Organ of Basal Actinopterygii}

The artificial grouping basal actinopterygians refers to the orders Amiiformes and Semiontiformes of the neopterygians and the orders Acipenseriformes and Polypteriformes, often included together as Chondrostei (see Nelson, 1994). Reference to "lower" actinopterygians is avoided because this usually refers to only Polypteriformes and Acipenseriformes and we wished to include amids and semionids in the present discussion; the latter are often referenced as "higher" actinopterygians (Gardiner, 1993). It is emphasized that the relationship of these four orders with one another and with the other major actinopterygian group (Teleostei) is still a matter of great controversy (Gardiner et al., 1996; Grande and Bemis, 1996). The name Holostei was originally used for a group of actinopterygians which included Amia calva (the bowfin), Lepisosteus spp. (gars), and Polypterus (bichirs). Parsimony analysis shows that Amia and the gars are a paraphyletic grouping and that the bowfin is more closely related to teleosts than to the gars (Gardiner et al., 1996). As recently pointed out by Conlon et al. (1998), the position of the polypterids is uncertain. However, the comparison made by these latter authors on the primary structures of insulin and glucagon from Polypterus with those from the gar and bowfin showed both a close relatedness among the three species and also their basal actinopterygian position (Conlon et al., 1998).

Published descriptions of the islet organ in both Polypterus and Amia have been cursory (Epple and Brinn, 1975). In both species the islet tissue is found throughout the widely dispersed exocrine acini, with no distinct islet accumulation in Amia but in Polypterus there is a tendency for aggregation near the junction of the bile duct at the intestinal-stomach junction. In the reedfish Calamoichthys, another Polypteridae, the islets are more widely dispersed but a large islet is present in the liver; the islets of this species contain four ultrastructurally distinct cell types (Epple and Brinn, 1975; Mazzi, 1976). To our knowledge, islet histology for Polypterus has not been performed. In Amia, Epple and Brinn (1975) used histochemical procedures and some electron microscopy to identify B and D cells, flameshaped cells, and two other unidentified acidophilic cells. Immunohistochemistry has revealed that the bowfin islets contain cells immunoreactive to antisera against insulin, somatostatin, and peptides of both the glucagon and pancreatic polypeptide families (Figs. 2c and $2 \mathrm{~d}$ ). Therefore, the islets of the bowfin contain the four cell types characteristic of the islets of more derived Actinopterygii. However, a unique character to the islets is that one of the cell types contains cytoplasmic crystalline inclusions (Fig. 4). A more detailed description of the GEP system of the bowfin will appear elsewhere.

Epple and Brinn (1975) reported that the islets in the pancreas of the gar, Lepisosteus spp., are more aggregated near the bile duct than in the polypterids. They reference an "islet organ" as a large aggregation of islets within the exocrine pancreas near the lower portion of the bile duct. A more recent study used serial sections and confirmed the highest distribution of islets ("Brockmann body like islet accumulations") near the papilla of the extrahepatic common bile duct but small islets were also distributed over the length of this duct, along the gall bladder, and in the mesentery adjacent to the anterior intestine (Groff and Youson, 1997). These descriptions resemble those given for islet aggregates in Salmoniformes (Wagner and McKeown, 1981; Wang et al., 1986; Nozaki et al., 1988a,b). It is tempting to use this single morphological feature to suggest some phylogenetic relationship of this Semionotiformes and salmonids but present taxonomic classification based on many features, including fossils, would not support this view (Gardiner et al., 1996). Immunohistochemistry of Lepisosteus islets indicated the presence of A, B, D, and F cells in a typical higher actinopterygian distribution (Groff and Youson, 1997). However, correlated fine structural and immunocytochemical observations revealed $\mathrm{B}$ and $\mathrm{D}$ cells and $\mathrm{a}$ 
third cell type, A/F, which colocalized peptides of the glucagon and pancreatic polypeptide families in the same cell and often in the same granules (Groff and Youson, 1998). It is uncertain whether there is any phylogenetic significance to this latter observation.

The distribution of pancreatic tissue in Chondrostei (Order Acipenseriformes, families Acipenseridae and Polyodontidae, sturgeons and paddlefishes, respectively) needs some specific attention (Epple and Brinn, 1987). In the sturgeon, Epple and Brinn (1975) found no Brockmann bodies and "mammalian-like" (small?) islets spread throughout the pancreas but perhaps a little more common near the liver hilus. The islets of Polyodon are more scarce and are of smaller average size than those in the sturgeon, perhaps because the absence of any distinct connective tissue capsule. Weisel (1972) also emphasized the absence of a Brockmann body in the paddlefish. Therefore, the present picture of the chondrostean pancreas is a system of widely dispersed small islets without any great tendency for aggregation (as seen in Fig. 1i). Since the tendency is for aggregated islets or large islets (Brockmann bodies or principal islets, respectively) in more derived actinopterygians, the most basal islet distribution seems to be present in one of the most basal of Actinopterygii.

\section{Islet Organ of the Sarcopterygii}

There are three extant groups of sarcopterygians, Actinistia (e.g., Latimeria), Dipnoiformes (lungfishes), and Tetrapoda (Cloutier and Ahlberg, 1996). The first two are groups of fishes with lobed fins but it is the dipnoans which are the living sister group to the tetrapods (Cloutier and Ahlberg, 1996). There has been no extensive histological examination of the pancreas of the coelacanth, Latimeria. Epple and Brinn (1975) refute the description of "groupes d'acini pancrétiques" by Millot and Anthony (1972) but do agree with Grossner (1968) that the pancreas is a compact, extraintestinal organ that they refer to as the primitive gnathostome type. Epple (1969) described islet cells of A, B, and D varieties along the outside of pancreatic ducts and thus, the islet topography of Latimeria resembles that in cartilaginous fishes.

In the dipnoans the pancreas of both Protopterus and Lepidosiren is described as in an intraintestinal location
(Epple and Brinn, 1975) and, more explicitly in a later study of Protopterus aethiopicus, as located in the wall of the cranial portion of the midgut or adjacent to the layers of the tunica muscularis (Scheuermann et al., 1991). In Protopterus annectens the pancreas is associated with the more cephalic and dorsal intestine and either between the intestinal serosa and submucosa (small specimens) or also spreading to the submucosa of the spiral folds in large specimens. Epple and Brinn (1975) mention a few encapsulated islets in P. annectens. In the more recent study, spherical islets of different sizes are described, with the small- and medium-sized ones located in cephalic regions of the pancreas near exocrine ducts (Tagliafierro et al., 1996). The endocrine portion of the pancreas of P. aethiopicus is segregated into a large ( $2 \mathrm{~mm}$ diameter), encapsulated primary islet organ (Brockmann body) with a variable number of smaller accessory islets (Scheuermann et al., 1991). This description of islet arrangement in Protopterus spp. would fit well with that found in the more derived euteleosts described above. Tagliafierro et al. (1996) came to the same general conclusion. However, given the location of the pancreas relative to that of euteleosteans, it does seem fitting that Epple and Brinn (1975) should consider the Protopterus isletpancreas system a unique entity and give it a separate status. The descriptions of islet distribution in the Australian lungfish, Neoceratodus forsteri (Rafn and Wingstrand, 1981; Hansen et al., 1987), seems different from that of Protopterus spp. (Tagliafierro et al., 1996). The distribution and size of islets in Neoceratodus are tetrapod like (Rafn and Wingstrand, 1981). Since these genera are representatives of two different dipnoan families, one wonders whether this is a further example of the utility of islet morphology as a character. On the other hand, one must be careful about general speculation concerning the phylogenetic development of characters when there has been independent specialization within Dipnoiformes. The distribution of immunoreactivity to antisera against insulin, somatostatin, glucagon, and pancreatic polypeptide (PP) in all lungfish species is similar to that of other fishes, including the colocalization of glucagon and PP and different distribution of cell types between large and small islets (Hansen et al., 1987; Scheuermann et al., 1991; Tagliafierro et al., 1996). 
6) $\because \begin{aligned} & \text { Insulin cell of open and } \\ & \text { closed type, respectively }\end{aligned}$

Somatostatin cell of open and
closed type, respectively

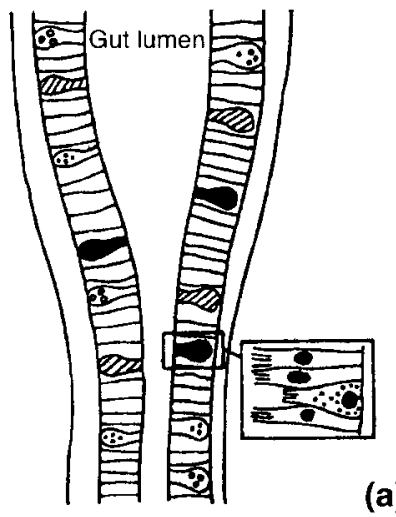

(8) Glucagon / GLP

1 PP cell

6oth Glucagon and PP

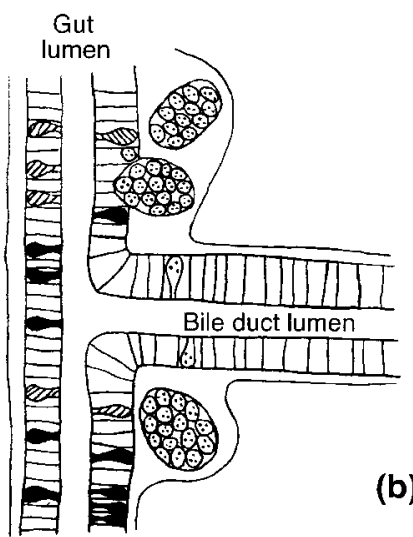

(c)

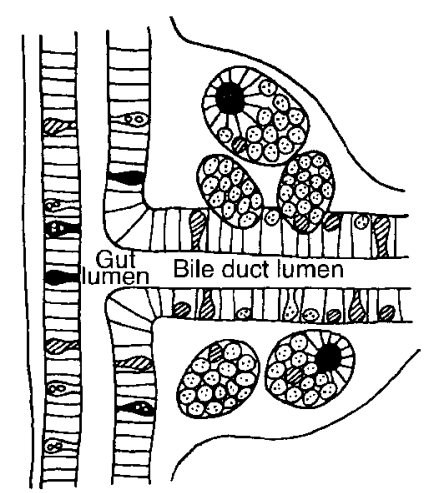

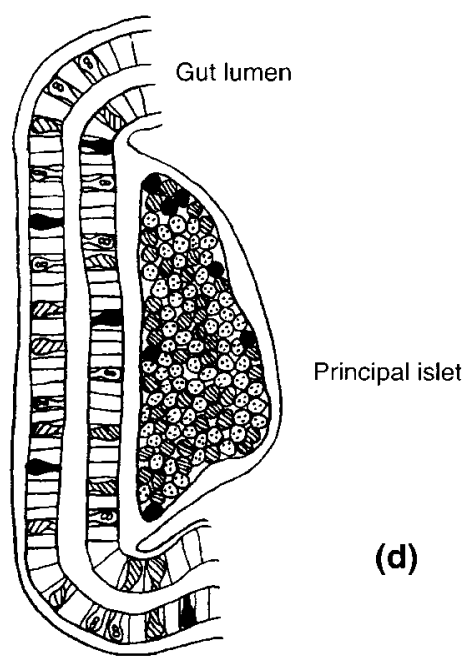
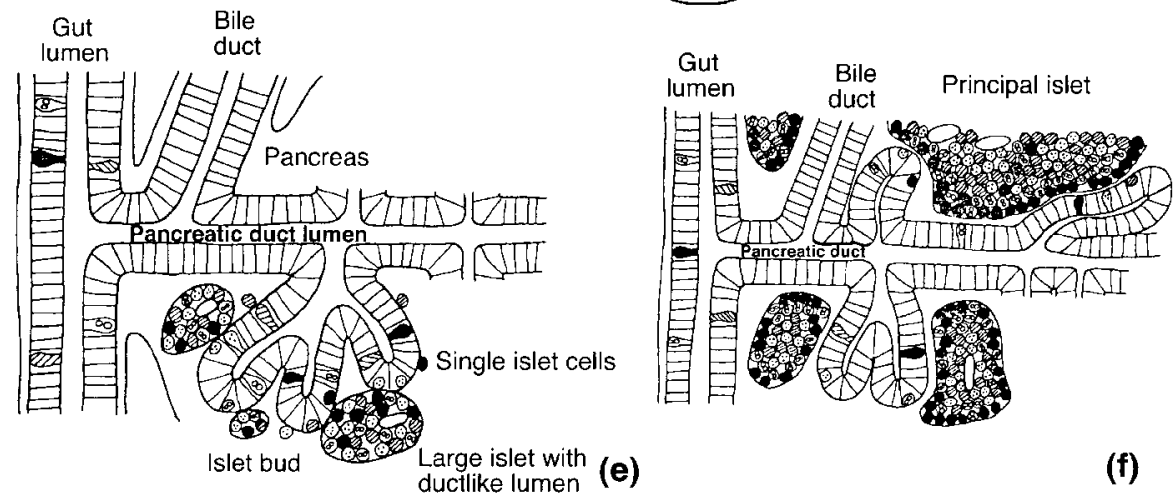


\section{Summary: Phylogenetic D evelopment of the GEP System in Bony Fishes}

The EP system has been examined in only a token of the total number of nearly 24,000 species of Actinopterygii, the ray-finned fishes. The islet tissue of all species so far studied has cells possessing four types of peptides: insulin, somatostatin, glucagon, and peptides of the pancreatic polypeptide family (Fig. 3f). There are variations in the distribution of these peptides within the gastrointestinal component of the GEP but the variations do not reflect any consistent phylogenetic pattern. In contrast, there seems to be some phylogenetic developmental pattern in islet tissue distribution and arrangement among the actinopterygians. In the more basal (nonteleost) actinopterygians (sturgeon, paddlefish, gar, bowfin, polypterids) there is a tendency for islets of various sizes to be scattered throughout the diffusely distributed exocrine tissue (Fig. 1i). The largest of the islet masses (principal islets) are mostly present near the point where the extrahepatic common bile duct meets the intestine but there are not concentrated aggregates (Brockmann bodies). Among the lower teleosts, elopomorphs (eels) and osteoglossomorphs (bonytongues), the latter group reflects the pattern of islet distribution described above for the basal actinopterygians. Islet distribution and arrangement among bonytongue species is consistent with taxonomic relatedness. Descriptions of islet distribution in eels are inconsistent but principal islets in one species may represent a phylogenetic trend seen best in the salmonids. Coho salmon and rainbow trout, considered more generalized euteleosts, have islets aggregated into a specific area of the exocrine pancreas termed the islet organ or principal body, which may be the forerunner to the Brockmann body. Small islets are also scattered throughout the remaining pancreas. This pattern is also seen in other generalized euteoleosts, cyprinids, and catfishes. All the more derived eutel- eosts have at least one principal islet in the Brockmann body, a large mass of islet tissue with or without a capsule of accompanying exocrine acini (Fig. 1j). Principal islets (as part of a Brockmann body), in addition to smaller scattered islets, are present in some species (e.g., percids). The ultimate in phylogenetic development of islet tissue arrangement in the actinopterygian islet organ may be the presence of all islet tissue in only discrete large bodies, the principal islets (e.g., anglerfish, sculpin). If principal islets are the endpoint, then their development can be traced through phylogeny of the actinopterygians. In addition, there is some evidence to suggest that the form taken by the endocrine pancreatic homolog in actinopterygians has utility as a taxonomic character.

The compact pancreas of the fishes of Sarcopterygii seems more tetrapod like in its location but evidence of principal islets in at least some dipnoans is more similar to the situation in the derived euteleosts. These data are support for the view "that a lungfish shares more characters with a cow than a salmon" (see Cloutier and Ahlberg, 1996) but also suggest that they share some characters with higher actinopterygians. This common character my reflect similar ontogenetic patterns in the two divergent groups of bony fishes.

\section{General Morphology of the Islet Organ in Chondrichthyes}

The pancreas of extant chondrichthyans is a distinct compact organ (Figs. 1g, h) which reflects an early state of combined exocrine-endocrine relationship among vertebrates (Epple and Brinn, 1987). In elasmobrachs (sharks, skates, and rays) the pancreas is of an irregular, often bilobed, (dorsal and ventral portions) shape (Sekine and Yui, 1981) and it usually lies below the anterior end of the intestine and extends as far as the pyloris. In the holocephalan (chimeras) the pancreas is

FIG. 3. Diagrammatic representation of endocrine cell types in the epithelium of the gut, bile duct, pancreatic ducts, and islet tissue of a protochordate (a), larval (b) and adult (d) lampreys, hagfish (c), an elasmobranch (e), and a teleost (f). Note endocrine cells in the gut of the protochordate, one-hormone islets in the larval lampreys derived from the gut epithelium, the two-hormone islet tissue derived from the bile duct in hagfish, and the three-hormone principal islet in the adult lamprey. Up to this point in phylogeny, glucagon-family peptides are confined to the gut epithelium but in cartilaginous (e) and bony (f) fishes are also included in the islets (four-hormone islets). The islet organ of the elasmobranch is confined within a compact pancreas and the islet tissue is intimate with the endocrine cells of the pancreatic ducts. In the teleost, a principal (partially shown) and secondary islets are present among pancreatic ducts and acini but were derived during early development from the gut epithelium; a, c, e, and f were modified from Falkmer (1985a) and are reproduced with permission. 

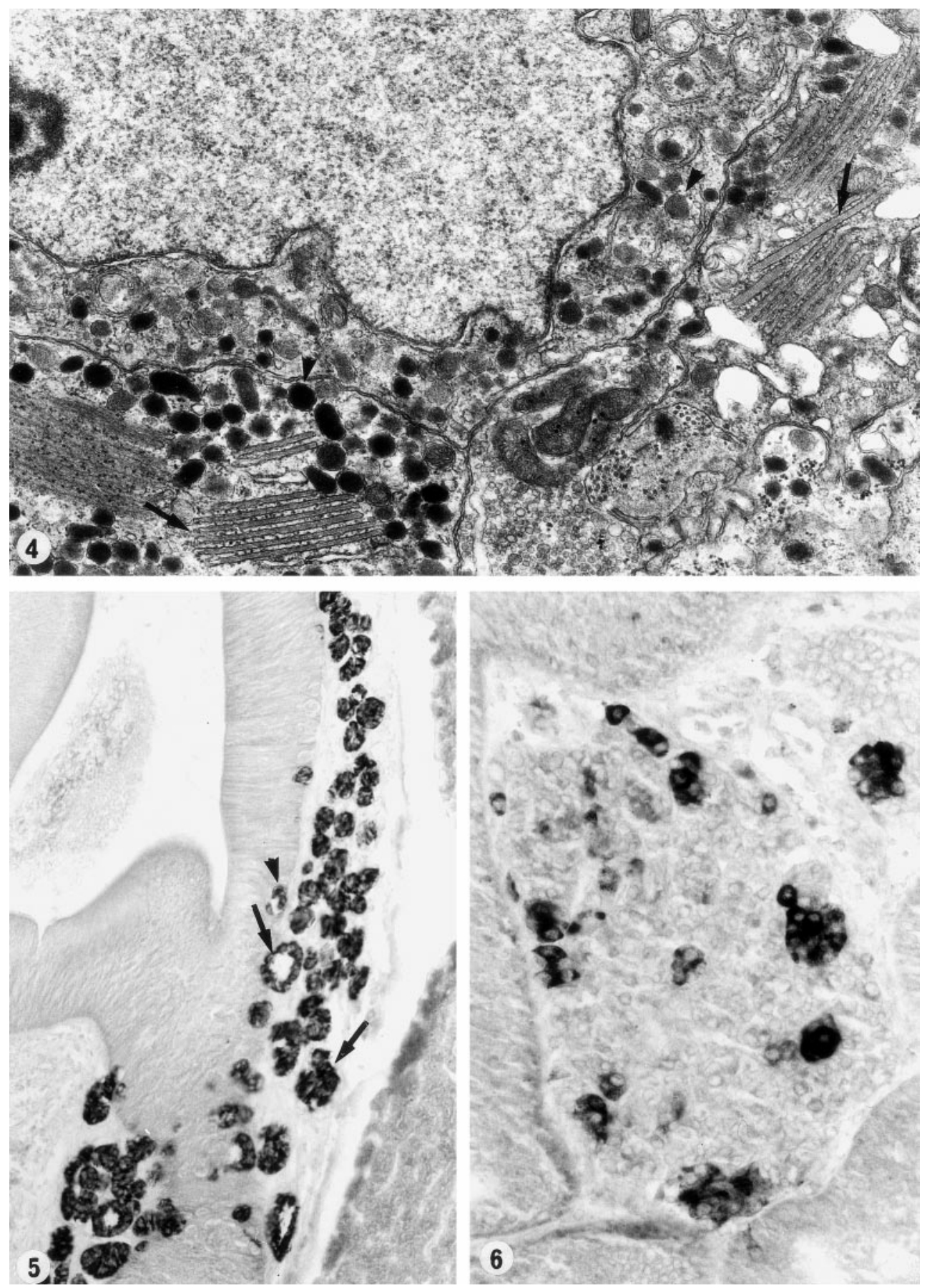

FIG. 4. Electron micrograph of an islet cell of unknown type from the bowfin $A$. calva, which contains many electron-dense granules (arrowheads) and parallel arrays of crystalline inclusions (arrows); original magnification, $\times 18,000$.

FIG. 5. The islet organ of a larval lamprey, Petromyzon marinus, has insulin-positive follicles both free (arrow) from and attached to (arrow) the intestinal epithelium but also intraepithelial aggregates (arrowhead) of similarly stained cells; peroxidase-anti-peroxidase (PAP) technique; original magnification; $\times 300$.

FIG. 6. The cranial principal islet of adult Petromyzon marinus possesses numerous D cells identified by their immunoreactivity to anti-somatostatin-14 antibody; PAP technique; original magnification; $\times 300$. 
more band like, lying along the hepatic portal channel (Jollie, 1973). Epple and Brinn (1986) emphasized the marked difference in the form of islet tissue within these two groups of cartilaginous fishes (Figs. $1 \mathrm{~g}$ and 1h). The ancestral group of Chondrichthyes is not known but the two subclasses are likely a monophyletic unit and it is possible that they had common origins (Nelson, 1994). Holocephalans are believed to have the most ancient lineage among chondrichthians and this fits well with the view of Falkmer (1995) that they display the first pancreatic gland in gnathostome phylogeny. However, Fujita (1962) had previously furnished a detailed description of islet morphology of the ratfish which would tend to contradict the Falkmer (1995) conclusion. It is particularly noteworthy that the holocephalan pancreas has a general morphology like that of mammals, with diffusely distributed islets throughout the exocrine parenchyma. Sometimes the islets are large but they are not principal islets. A deviation from that of other gnathostome fishes is that only insulin, somatostatin, and glucagon peptides are localized in the islets; pancreatic polypeptide immunoreactivity is present in the intestine and in the pancreatic ducts (Stefan et al., 1981). In contrast, Epple and Brinn (1986) described a few F cells and a X cell in the islets; the $X$ cells represent $50 \%$ of all islet cells in holocephalians (Epple and Brinn, 1987) and store a glucagon-like peptide closely related to mammalian oxyntomodulin (Conlon et al., 1987). Thus, despite the suggestion of a more ancient lineage of holocephalans compared to elasmobranchs, Epple and Brinn (1986, 1987) support the view of Fujita (1962) that the holocephalan pancreas is intermediate in form to that of elasmobranchs and "higher" fishes.

In contrast to the above, Falkmer (1995) equates the elasmobranch pancreas to be "of the well-known mammalian type" on the basis of both gross and microscopic features and to be more advanced than the holocephalan pancreas. In particular, the islets have the primary four cell types (A, B, D, and F), as seen in most bony fishes through to mammals (Jönsson, 1991). Moreover, an elegant histochemical study of a shark has revealed more than just the classical islet cell types, e.g., several amphiphil cells (Epple, 1967). Islet cells in a skate are immunoreactive to both somatostatin and pancreatic polypeptide antisera. Immunoreactivity for insulin-like growth factor- 2 is present in B cells and is considered to reflect both the ancient origin and the conserved nature of this molecule among vertebrates. (Reinecke et al., 1994). In addition, immunoreactivity has been noted in the islets to antisera against enkephalins, FMRF amide, gastrin/cholecystokinin/caerulein, and neurotensin (Jönsson, 1991). Collectively these data suggest, as predicted by Epple (1967), that elasmobranchs have many more islet cell types than the holocephalan islets. As in holocephalans, the islets of elasmobranchs have a relationship with pancreatic ducts (Fig. 3e), but the relationship is quite variable. In fact, Thomas (1940) described three types of islet-duct relationship in elasmobranchs. These are islet cells as part of the ducts, groups of islet cells budding from the duct, and islets close to, but independent of, the ducts. Even from the small number of descriptions presently available it seems that there may be considerable variation in the types of islet-duct relationships within orders and families of elasmobranchs. For example, the pancreatic endocrine cells of the ray Dasyatis akajei are described as representing the most "primitive" arrangement among elasmobranchs in being present as a layer beneath an inner ductular epithelium (Sekine and Yui, 1981). In contrast the starry ray, Raja radiata, is described as having large and small islets (Jönsson, 1991). Islets are also described in the sting ray, Raja clavata, but at least some have intimacy with the pancreatic ducts (Reinecke et al., 1992, 1994). Islet morphology and the islet-duct relationship also seems to differ between selachians, e.g., a dogfish and a shark species (Epple and Brinn, 1975; Kobayashi and Ali, 1981; Jönsson, 1991).

The endocrine cells of the gastrointestinal system of elasmobranchs has received a great deal of attention over the years and the reader is referred to several of the early and recent reports (El-Salhy, 1984; Cimini et al., 1989; Tagliafierro et al., 1989; Yui et al., 1990; Chiba et al., 1995; Chiba, 1998). However, despite the many species of elasmobranchs that have been investigated no phylogenetic pattern involving the presence/ absence or distribution of regulatory peptides in the stomach and intestine has emerged.

\section{Summary of the Phylogenetic D evelopment of the Islet Organ in Chondrichthyes}

The distribution and form of the pancreatic endocrine tissue in cartilaginous fishes seems to bear no 
relation to that observed in bony fishes. There is a view, partially based on the presence of three primary islet cell types, that the holocephalan pancreas is the first discrete pancreas to appear in gnathostome evolution (Falkmer, 1995) but it is remarkably similar in gross and microscopic appearance to that found in tetrapods (Fig. 1g). A contrasting viewpoint is that islet cell types simplified rather than diversified during the phylogenetic development of the gnathostome pancreas (Epple and Brinn, 1987). In this latter context, the islets of selachians among the elasmobranchs may represent a more ancient islet from that seen in holocephalans. The mammalian-type, compact pancreas is also depicted in elasmobranchs but its microscopic appearance is reflective of a pancreas in a state of morphogenesis of islets. Since the holocephalans are generally believed to have the more ancient lineage of these two subclasses (Schaeffer, 1981), phylogenetic development of the pancreas, and in particular the arrangement and form of the islet tissue, is not clear between the two groups. With this one character it is hard to see an immediate phylogenetic developmental pattern of the two subclasses. On the other hand, variations in islet arrangement and form in elasmobranchs (selachians and batoids) has excellent potential for the demonstration of the phylogenetic development of an organ system within a vertebrate subclass. The relevance of the chondrichthyan islet organ to the phylogenetic development of this organ in the vertebrate group as a whole is also not clear. The above data must be interpreted in light of results from a recent mtDNA analysis that show Chondrichthyes representing a terminal position in the piscine tree and diverging from other gnathostomes much earlier than had been previously predicted (Rasmussen and Arnason, 1999). For instance, their cartilaginous skeleton is not the forerunner to the bony skeleton of Osteichthyes or higher vertebrates. Thus the islet organ of Chondrichthyes is likely not basal to that of other gnathostome groups.

\section{Morphology of the Islet Organ in Agnatha}

Lampreys and hagfishes are the only extant jawless fishes or agnathans. They may have shared a common ancestor in the early Cambrian but they diverged very early in their evolutionary histories. Hagfish are likely the most ancient of living vertebrates, since their origin can be traced back to close to 550 million years. Lampreys, on the other hand, have had a rather conserved evolution since they first appeared 350 million years ago (Forey and Janvier, 1994). It is important to our discussion that the reader be aware of the differences in the life histories of the two agnathans. Hagfish are entirely marine and have a direct development following hatching; that is, the postembryonic young resemble the adults. In contrast, lampreys are represented by anadromous and freshwater species and they have an indirect developmental interval in their life cycle. The freshwater larvae appear after hatching and after 2-7 years they undergo a metamorphosis to acquire juvenile adult characters and to permit adult behavior (Youson, 1988). The phylogenetic history of the enteropancreatic (EP) system in agnathans has recently been discussed (Youson, 1999) and the reader is referred to this article for more detail and an extensive literature review. The present description will concentrate on details of the agnathan pancreas which are relevant to the general discussion of the ontogenetic and phylogenetic developmental histories of the fish GEP system. This discussion would not be complete without some reference to these extant fishes with such ancient lineages.

Hagfish. Falkmer (1995) describes the hagfish as the first vertebrate to have an islet organ. This organ is located at the junction of the extrahepatic bile duct with the intestine (Fig. 1f) and is an aggregate of islets or follicles of epithelial cells (Fig. 3c). The epithelial cells of the follicles surround a wide lumen in some, but not all, species and most of the cells (B cells) are immunoreactive with only anti-insulin serum; about $1 \%$ of the cells are D cells (Fig. 3c). Cells equivalent to those of the exocrine acini of other fishes are present in the intestinal mucosa of the hagfish (Fig. 1f). Falkmer (1995) states that this is evidence that the islets of Langerhans of the pancreas are phylogenetically more ancient than the exocrine acini and the first "endocrine pancreas" was a two-hormone gland (Falkmer, 1985). In contrast, to the situation in cartilaginous fishes, where islets are associated with pancreatic ducts, the hagfish follicles are intimately associated with the epithelium of the bile duct (Fig. 1f). The bile duct epithelium is also interspersed with insulin- and somatostatin-immunoreactive cells (Fig. 3c). The other two peptides usually found in the islets of other fishes, 
namely, pancreatic and glucagon family peptides, are present in the epithelium of the intestine along with somatostatin (Fig. 3c). Thus the EP system in hagfish is dispersed among three components, the intestinal and bile duct epithelia and an islet organ which is independent of exocrine acini.

Lamprey. Like hagfishes, there is no direct equivalent to a higher vertebrate exocrine pancreas in lampreys at any stage of their life cycle (Figs. 1b-1e). In most cases, the zymogen cells are interspersed among absorptive cells in the anterior intestine or a small diverticulum (Barrington, 1972; Youson, 1981) but Southern Hemisphere species have expanded intestinal diverticuli where these cells are located (Strahan and Maclean, 1969). An enlarged left diverticulum, the so-called protopancreas, of Mordacia mordax is considered a derived feature and reflective of the early divergence of the family Mordaciidae from the other lamprey families (Gillett et al., 1996). This latter view contrasts with that of Epple and Brinn (1987) but the two groups of authors are consistent in their opinion that a compacted mass of exocrine pancreatic-type cells evolved several times during vertebrate evolution.

In larval lampreys, the endocrine tissue is present as small islets or follicles in the submucosal connective tissue near the junction of the esophagus, the anterior intestine, and the extrahepatic common bile duct (Figs. $3 \mathrm{~b}$ and 5) in holoarctic species. In Southern Hemisphere species the islet aggregate is located near the confluence of the intestine, diverticula, and esophagus, for the bile duct enters the cephalic part of one of the diverticula (Fig. 1c). The term "islet organ" is not of common use to describe the islet aggregate in larval lampreys, but it was applied by Epple and Brinn (1986). Islet organ would also seem to be appropriate here, for in some species, such as, in the Southern Hemisphere, Mordacia mordax, the islets are highly compacted (Youson and Potter, 1993), like those in the hagfish. Some islets are contiguous with the epithelium of the anterior intestine but all are composed entirely of B cells (Figs. 3b and 5). Anti-insulin immunoreactivity is also present in some intraepithelial cell clusters of the anterior intestine (Fig. 5). Immunoreactivity to antisera against somatostatin and PP-family peptides is present in isolated cells of the anterior intestine but intraepithelial cell clusters are also PP immunoreactive (Fig. 3B; Cheung et al., 1991b). There is some question as to whether peptides of the glucagon family are present in the larval intestine; the majority of species so far examined show no immunoreactivity to either anti-glucagon or -glucagon-like peptide (Youson and Potter, 1993). Therefore, the larval lamprey EP system possesses a one-hormone, islet organ and, in general, the remaining most common regulatory peptides (somatostatin, PP-family, glucagon?) are confined to the intestinal epithelium. Insulin has been localized in the intestine of larval M. mordax (Youson and Potter, 1993) and just recently in the extrahepatic common bile duct of 35-day-old larvae of Petromyzon marinus (Youson, 1999).

The term islet organ has been used to describe the endocrine pancreatic homolog in adult lampreys (Falkmer, 1985a; Epple and Brinn, 1986). In the context of its use in other fishes of the present discussion, including hagfishes and larval lampreys, this term still seems appropriate for adult lampreys. Islet organ is a general term referring to the endocrine pancreatic homolog in a vertebrate, irrespective of its distribution (Falkmer, 1995). In adult lampreys, the islet tissue is compacted into one or two large bodies of lobules and there is no intervening exocrine acini or much connective tissue (Figs. 1d and 1e). The situation in adult lamprey is much like the principal islets (Brockmann bodies) described in the most derived euteleosts. In particular, principal islet usually refers to an isolated, single mass of islet tissue. There is a single cranial aggregate of isolated islet tissue in Southern Hemisphere species but all Northern Hemisphere species have both a cranial and caudal aggregate with an intermediate cord of cells between the two (Youson and Cheung, 1990). We have used the term cranial and caudal pancreas for these aggregates, but now admit that since there is no exocrine element associated with either aggregate, this term is not anatomically correct. Henceforth, it is now recommended that principal islet be used for the endocrine pancreatic homolog in adult lampreys. The islet organ in Southern Hemisphere species is a cranial principal islet (Fig. 1e). Since in the holarctic species the two largest aggregates are both structurally and morphogenetically independent and they are some distance apart, they should be referred to as cranial and caudal principal islets (Fig. 1d). The intermediate cord is secondary islet tissue. These three components comprise the islet organ in the Northern 
Hemisphere species. This definition of the islet organ in adult lampreys would fit well with previous interpretations (Falkmer, 1985a, 1995).

It was stated at the outset of this review that there would be little focus on the structure of peptides within the various groups of fishes. However, the interfamilial and intergeneric differences in the EP system of lampreys have proved intriguing. When morphological data of principal islets and structure of peptides of the EP system are compared among species, a picture is painted of the importance of examining more than one species, and the utility of the EP system in analysis of phylogenetic development, within a group of fishes.

The principal islets of adult lampreys are a threehormone tissue containing B, D, and F cells (Figs. 3d and 6); no immunoreactivity has been found for members of the glucagon family (Youson and Elliott, 1989; Youson and Cheung, 1990; Cheung et al., 1991a). Glucagon and glucagon-like peptide have been localized in the intestine, along with somatostatin and peptides of the pancreatic polypeptide family (Fig. 3d). PYY has been conserved among three genera, representing two families of lampreys (Wang et al., 1999a), but comparisons of amino acid sequences of somatostatins and insulin indicate some evolutionary pressure on these molecules. Extant lampreys share a common ancestral insulin gene, for their insulins all have the same 5-amino-acid extension at the $\mathrm{N}$-terminal of the $\mathrm{B}$ chain; this feature is not found in any other vertebrate (Plisetskaya et al., 1988; Conlon et al., 1995b; Youson, 1999). However, insulin of the Southern Hemisphere species Geotria differs by 17 amino acid substitutions from the identical insulins of two genera of holarctic lampreys, Lampetra and Petromyzon (Conlon et al., 1995b). This difference perhaps accounts for the fact that antisera against Petromyzon insulin would not immunostain Geotria B cells (Youson and Potter, 1993). In contrast, "large" forms of somatostatin isolated from the GEP system of each genus (somatostatin-35, -34, -33 for Lampetra, Petromyzon, and Geotria, respectively) differ markedly in their N-terminus but the C-terminus of each peptide is characterized by a variant form of somatostatin-14, $\mathrm{Thr}^{12} \rightarrow$ Ser (Andrews et al., 1988; Conlon et al., 1995b). This form of somatostatin is found only in the lamprey EP system, for brain somatostatin-14 of both Lampetra and Petromyzon is the invariant form found in the neuroendocrine and GEP systems of all other vertebrates examined to date (Sower et al., 1994; Conlon et al., 1995a). A tissuedependent, differential expression of a gene(s) encoding preprosomatostatin is also found between the intestine and the principal islet of Geotria (Wang et al., 1999b). These data serve as documentation for the common ancestry of the lamprey genera (variant somatostatin-14), that the divergence of Petromyzontidae and Geotriidae families is likely ancient (insulin), and that there has been considerable evolutionary pressure directed against the N-terminal of preprosomatostatin among the lamprey genera. It is noteworthy in the context of phylogenetic development of the agnathan EP system that hagfish and lamprey insulins and somatostatins show little similarity. However, a somatostatin-34 with an invariant somatostatin-14 at the C-terminus is found in the hagfish (Conlon et al., 1988). Thus the agnathan phyletic group is characterized by a dominant, islet organ somatostatin with a minimum of 33 amino acids. The persistence of these large somatostatins in agnathans and the difference in the C-terminus between hagfishes and lampreys are intriguing from the points of view of taxonomic relatedness, molecular processing, and biological activity.

The story of proglucagon in lampreys is still unfolding but it seems that there are two genes encoding for different glucagons in Geotria intestine and that Lampetra and Petromyzon each express only one, but a different, gene (Wang et al., 1999b). These data support the view of an early duplication of the glucagon gene in lamprey evolution. Recently it has been shown that the two glucagon genes are present in Petromyzon and that one encodes for glucagon-like peptide- 1 and a glucagon and a second encodes for glucagon-like peptide- 2 and another glucagon (Irwin et al., 1999). The view is that the duplication of the glucagon gene preceded the appearance of the first vertebrates.

\section{Summary of the Phylogenetic D evelopment of the Islet Organ in Agnatha}

Agnathans are unique among fishes in having a complete separation of their endocrine pancreatic homolog (islet organ) from the exocrine pancreatic equivalent which is present either in the mucosa of the intestine or in special intestinal diverticula (larva lampreys of Southern Hemisphere species). Assuming 
that hagfish are the oldest of the extant vertebrates, their endocrine pancreatic homolog is the first islet organ and it is a noteworthy comparison with gnathostome fishes that the lobules of this two-hormone organ are often confluent with the extrahepatic common bile duct. However, the insulin-only, islet organ of larval lampreys may represent the most basal of islet tissues present within a free-living vertebrate (Figs. 3b and 5). The three-hormone islet organ of adult lampreys may be looked at as an advancement over the islet organ of the more ancient hagfish (Fig. 3d). Familial variations in the distribution of the islet organ of adult lampreys is a specific taxonomic character which is a consequence of family-specific differences in morphogenetic events occurring during metamorphosis. A single, cranial principal islet is characteristic of Southern Hemisphere species, whereas the Northern Hemisphere species have two principal islets, cranial and caudal, and a cord of secondary islet tissue between these two islets (Figs. 1d and 1e). These data are consistent with the views of the earlier separation of the hagfish and lamprey lines (Forey and Janvier, 1994) and that, although the lamprey families likely arose from a common stock, divergence of Southern and Northern Hemisphere species occurred relatively early in the evolutionary history of lampreys (Potter and Hilliard, 1987). Moreover, the petromyzontids (Renaud, 1997) had a more conserved evolution than members of the two Southern Hemisphere families. Comparison of the primary structures of insulin, somatostatin, and glucagon among members of two lamprey families and between insulins and somatostatins of lampreys and hagfishes are providing additional support for these views on the phylogenetic development and variation of the EP system among agnathan species.

\section{PHYLOGENETIC ORIGIN OF THE FISH GEP SYSTEM}

Falkmer and his colleagues have long held the view that the origin of the vertebrate endocrine pancreas can be traced to what they call the brain-gut axis within the subvertebrate members of Phylum Chordata, the protochordates, and other deuterostomian invertebrates (Falkmer and Patent, 1972; Van Noorden, 1984;
Falkmer, 1985a,b, 1995). This view of the phylogenetic development of the vertebrate GEP system contends that peptides common to the vertebrate system first appeared in the nervous system of lower invertebrates (Van Noorden, 1984) and then they appeared in endocrine cells of the gut of some protostomian and many deuterostomian invertebrates (Falkmer, 1995). Data from the protochordates are particularly relevant here, for it is from this group that the first vertebrates may have arisen (Romer, 1970) and these lower chordates show dual occurrence of many regulatory peptides in both the brain and gut, i.e., a culmination of the phylogenetic development of the brain-gut axis (Falkmer, 1995). There is no direct equivalent to the vertebrate islet organ among the protochordates (Figs. 1a and 3a), i.e., Urochordata and Cephalochordata. Although numerous studies of protochordate gut immunohistochemistry had preceded that of Reinicke (1981), his investigation of the mapping of polypeptide hormone immunoreactivity (insulin, glucagon, somatostatin, and pancreatic polypeptide) in the digestive tract of Branchiostoma lanceolatum has been one of the most comprehensive (Fig. 3a). Further immunohistochemical, biochemical, and molecular studies have also indicated that in Branchiostoma spp. there is a common gene encoding insulin and insulin-like growth factor (IGF) and they are likely synthesized in the same cells of the gut and brain (Chan et al., 1990; Reinecke et al., 1993a). In fact, IGFs and insulin may have originated from the same ancestral molecule (Plisetskaya, 1989a). However, the two cDNAs recently isolated from the tunicate Chelyosoma productum likely code for separate products, a proinsulin molecule and a preproIGF (McRory and Sherwood, 1997). An insulin-like peptide and an IGF-1 coexist in the intestinal cells of another tunicate, Ciona intestinalis (Reinecke et al., 1999).

The next step in the phylogenetic development of the vertebrate endocrine pancreas is the budding of these gut endocrine cells from the mucosal epithelium to produce the first islet organ. The reader is referred to the schematic presentation of Epple and Lewis (1973), where several possible developmental pathways, the role of open- and closed-type cells in the gut, and the ontogenetic relationship to the exocrine pancreas are discussed. These various interpretations are important in light of the facts presented in this review that the major piscine groups diverged early in their evolution 
and their islet organs took on different forms. For instance, the compacted pancreas of Chondrichthyes is a consequence of a phylogenetic-ontogenetic pathway involving an intimacy of pancreatic ductular and islet cells, whereas agnathans used a pathway involving an intimacy of bile ductular and/or intestinal cells with islet cells. The step as represented in the simplest form from a hypothetical protochordate-like precursor is the one-hormone islet organ of the larval lamprey which originates primarily from the intestinal epithelium (Fig. 3b). The hagfish deviated somewhat from this phylogenetic developmental trend by having the endocrine cells of this two-hormone islet organ originate from the extrahepatic common bile duct (Fig. 3b), although many regulatory peptides are present in the intestine (Van Noorden, 1990). Furthermore, IGF-1 immunoreactivity is present in the intestine, islet organ, and brain of hagfish (Reinecke et al., 1991, 1993b) and, as in the protochordate intestine (Reinecke et al., 1993a, 1999), insulin and IGF-1 immunoreactivity is colocalized. The above discussion emphasizes how the study of the phylogenetic development of the vertebrate islet organ in some ways contributes to the broader analysis of the origins of vertebrates in general. However, beyond the simplest islet organ as seen in larval lampreys, it is becoming clear that the definitive islet organs of members of Chondrichthyes and Actinopterygii are likely a consequence of their early divergence and terminal position relative to piscine gnathostomes which led to the tetrapods.

\section{ONTOGENY OF THE FISH GEP SYSTEM}

\section{Background}

In the past decade it was emphasized (e.g., Andrew, 1984) that it was unfortunate that our knowledge of the factors involved in functional and structural maturation of fetal pancreatic endocrine cells was so poor, for this information had clinical value, particularly in transplant technology (Reddy and Elliott, 1988; Dubois, 1989). This paucity of information was partially due to the fact that the earlier views of a neural crest origin of islet cells (Pearse, 1969; Pearse and Polak, 1971) had been refuted through experimental studies (Andrew, 1976; Le Douarin, 1988). Rombout et al.
(1978) used fluorescent microscopy, autoradiography, and electron microscopy to study development of the GEP system in the fish Barbus conchonius and concluded that the GEP cells are not derived from the neural crest. Although the endodermal origin of islet cells is now accepted, nerve cells and islet cells share many morphological, functional, and biochemical traits (Fujita, 1989; Teitelmann, 1990; Reddy et al., 1997).

Within this present decade there has been a remarkable advance in our knowledge of the events of the ontogeny of islets of Langerhans in mammals. In particular there has been a dramatic shift from the previously held concept of one hormone/cell during ontogeny to a wider acceptance of a precursor cell for the four types of principal endocrine cell types which ultimately localize insulin, glucagon, somatostatin, and pancreatic polypeptide (Hashimoto et al., 1988). That is, there is a series of stages in the differentiation of the islet cells and one of these stages is that they often acquire more than one hormone (Zabel et al., 1994). Early in development glucagon and insulin are usually localized in the same cell (Teitelmann et al., 1993). Somatostatin and pancreatic polypeptide are localized in cells much later in development but at one point in mouse development PYY is present in all four principal islet cell types (Upchurch et al., 1994). The second advance has been in the investigation of factors regulating the development and expression of the four principal hormones. For example, Pax genes 4 and 6 are required for development of the mouse pancreas with Pax 6 directing the differentiation of A cells (St-Onge et al., 1997). A new member of the protein tyrosine phosphatase (PTP) family, called PTP-NP (for neural and pancreatic), is a receptor-type transmembrane molecule and an early marker of development (Chiang and Flanagan, 1996). Adrenomedullin is capable of modulating insulin secretion (Martinez et al., 1996) and during development it is expressed by islet cells (Montuenga et al., 1997). This hormone appears first with cells containing glucagon, eventually within all principal islet cell types, and ultimately with only those containing pancreatic polypeptide (Martinez et al., 1998). It is concluded that early expression of adrenomedullin is critical for islet development.

Studies of the ontogeny of the fish islet organ are few but such studies are both plausible and important, particularly in light of the potential use of fish princi- 
pal islets as tissue for xenotransplanting (Wright et al., 1998; Yang et al., 1999). Fish can undergo one of two types of postembryonic development: indirect, with a dramatic metamorphosis of larvae into the juvenile, and direct, with a gradual differentiation and growth of the fry into the juvenile (Youson, 1988). The reader should keep these two types of development in mind during the subsequent discussion.

The present evidence is that there is a common origin of islet tissue in all vertebrates, that is, from embryonic endoderm, the primitive gut, or their derivatives (Epple and Brinn, 1986). In mammals, the pancreas results following fusion of ventral and dorsal evaginations of the primitive gut. Pancreatic ducts eventually produce the cells which create both the acini and endocrine cells (Teitelmann et al., 1987). Early investigations of the development of the islet organ in fishes are those of Baron (1935) and Vorstman (1948). Epple and Brinn (1986) emphasize that three anlagen are involved in the development of the pancreas in vertebrates "above" Chondrichthyes. The ventral anlagen produces a few scattered islets. In contrast, in the dorsal anlagen there is an intimacy with the exocrine and endocrine components which may account for the variation in size and distribution of islets in organisms above Chondrichthyes. A close relationship of the two pancreatic components results in a dissemination of small islets, whereas large islets (principal islets) develop when intimacy (invasion) of exocrine acini is marginal. It was concluded that this relationship of exocrine and endocrine components of the pancreas has little functional significance (Epple and Brinn, 1986). However, these latter authors have emphasized the importance of blood circulation and innervation to pancreatic ontogeny (Epple and Brinn, 1986, 1987). Although subsequent studies have described nerve terminals in definitive islet organs of fish, there is nothing further to report on the significance of innervation to pancreatic morphogenesis in this vertebrate group.

\section{Bony Fish}

The development of the teleost pancreas from a gross anatomical perspective had been most extensively investigated in sea bass, D. labrax (Diaz et al., 1989). The primordial pancreas first appears as a posterodorsal thickening on the right side of the foregut of the posthatched fry. Eventually the right thickening buds laterally to produce a pancreatic tissue which spreads along blood vessels and the intestinal wall. Light and electron microscopic analyses (Guyot et al., 1998) have shown that by the second day after hatching of the gilthead sea bream, S. aurata, the bud is a cell mass differentiated into two separate cell populations, exocrine and endocrine cells, with the latter forming a small islet (Fig. 7). The above viewpoint of Epple and Brinn (1986) that dorsal and ventral anlagen have differential participation in development of the teleost pancreas was subsequently demonstrated in a study of a four-stage development of D. labrax (García-Hernández and Agulleiro, 1992). A principal islet developed dorsally and later several small islets appeared more ventrally. Five types of cells (A, B, D1, D2, and F) have been distinguished in the principal and smaller islets by both immunohistochemical and fine structural features (Agulleiro et al., 1994). In earlier stages of development a "primordial cord" is enclosed in the dorsal wall of the anterior midgut and it was composed of cells immunoreactive to antiSST-25 (D1) and to anti-insulin (B cell). This cord passes through a primitive islet with the same cell types and eventually into a single islet surrounded by exocrine acinar cells. This islet had a regional distribu-

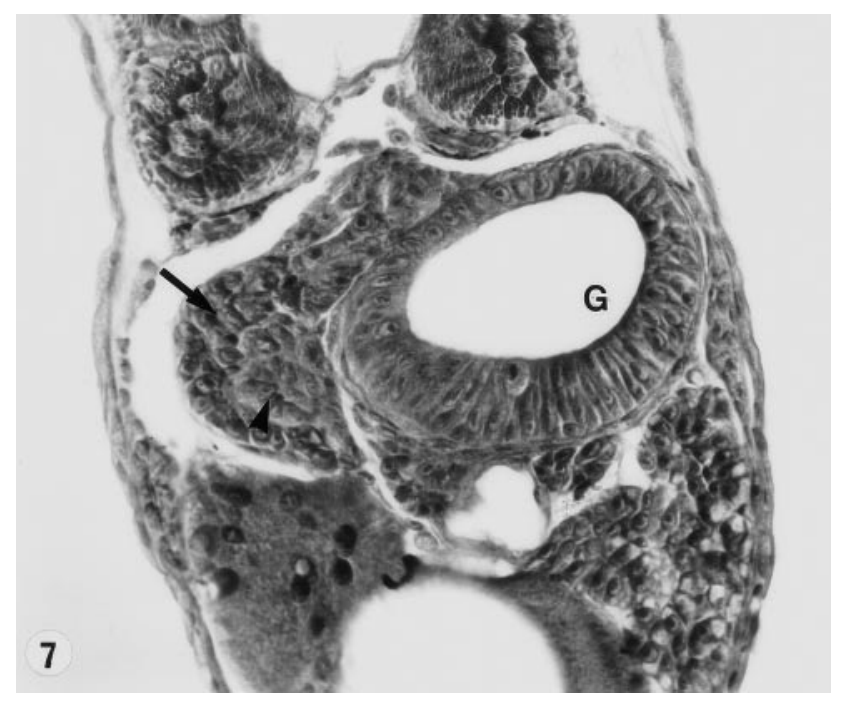

FIG. 7. Transverse section of a 2-day-old prelarva of the gilthead sea bream, Sparus aurata, showing islet tissue (arrowhead) and exocrine pancreatic tissue (arrow) which has developed from a primordial cell mass originating from the gut $(\mathrm{G})$; original magnification; ×1200. (From Guyot et al., 1998.) 
tion of peripheral D1 cells, the most peripheral A cells, the innermost B cells, and the intervening D2 cells. In addition, "primordial islets" developed in the ventral pancreas from the epithelium of pancreatic ductules (García-Hernández and Agulleiro, 1992; García-Hernández et al., 1994a) and they are composed of D1 and $B$ cells. It was concluded that, in contrast to the situation described above in mammals, each cell type develops independently, i.e., not from a common precursor cell (García-Hernández et al., 1994a). However, there may be a common precursor cell for A and $\mathrm{F}$ cells (García-Hernández and Agulleiro, 1992). Another noteworthy difference to mammals was the absence of glucagon early in development of islets in this species (see also Beccaria et al., 1990) but perhaps insulin and somatostatin interact early in development (before larval feeding) to regulate differentiation (GarcíaHernández et al., 1994a).

Immediately after hatching of larvae of both the turbot Scophthalamus maximus (Berwert et al., 1995) and the gilthead sea bream S. aurata (Guyot et al., 1998), clumps of B cells are the first to appear in a single primordial islet located at the epithelium of the undifferentiated intestinal tube. In the turbot, insulinimmunoreactive cells persisted as this islet enlarged and new, smaller islets formed. The onset of feeding in this species was correlated with the appearance of D cells (these usually first) and A cells but there was a variation in distribution in the different-sized islets. The principal islet had an intermingling of B and D cells but smaller islets had D cells at the periphery with A cells. F cells were the last cell to appear, 12 days posthatching. Immunoreactivity to anti-IGF-1 appeared at day 11 in F, A, in some D cells, and some cells showed colocalization of the principal peptides; this was interpreted as corresponding to the beginning of the growth promoting effect of piscine pancreatic tissue. The ordered sequence of appearance of B, D, A, and $\mathrm{F}$ cells in the ontogeny of the turbot pancreas was interpreted as reflecting Haeckel's biogenetic rule (see Gould, 1977) that "ontogeny recapitulates phylogeny"; this is the same order that they seem to appear in phylogenetic development of the vertebrate pancreas (Berwert et al., 1995; also see earlier discussion).

A recent study used ELISA to show the highest levels of insulin to be at the hatching stage of gilthead sea bream when the pancreas primordium is about to form (Guyot et al., 1998) and endotrophism (yolk absorption) is the primary source of nutrition (Fig. 8). This insulin, likely of maternal origin, is probably used for organ growth and cell differentiation, which are prominent features of developing larvae during the 0 to 5-day posthatching period. Of particular importance at this time is the development of the liver, which is the essential organ when the larvae becomes exotrophic and carbohydrates are the main energy reserve (Guyot et al., 1995). The coordination of development of the islet organ, liver, and intestine are critical to the survival of the larva with respect to insulin production, glyconeogenesis, and absorption of an exogenous food source, respectively (Guyot et al., 1998).

The development of the gastrointestinal component of the GEP system in bony fish has received more attention than that of the islet organ (Rombout et al., 1978; Connes and Benhalima, 1984; L'Hermite et al., 1985; García-Hernández et al., 1994b; Reinecke et al., 1997). In addition to the differentiation of cells which contain the classical islet hormones, these studies have also shown the time and appearance of some of the hormones specific to the gastrointestinal component of the GEP system. For this latter group of hormones, the reader is referred to the most recent articles (GarcíaHernández et al., 1994b; Reinecke et al., 1997). For the sake of both brevity and conformity with the rest of this paper we will consider only the ontogeny of cells elaborating insulin, somatostatin, and peptides of the glucagon and pancreatic polypeptide families.

The ontogeny of gastroenteroendocrine cells in indirect developing bony fish has been studied in eels (L'Hermite et al., 1985) and the turbot (Reinecke et al., 1997). Eel leptocephali just prior to metamorphosis show only slight labeling for glucagon in the small intestine. However, after metamorphosis the glass eels show a fairly abundant glucagon immunoreactivity in the "duodenal bulbous" and scarce staining for glucagon in the small intestine and rectum. Anti-somatostatin immunoreactivity was present only in cells of the pyloric cecum and stomach at this stage. The pattern of glucagon and somatostatin distribution continued into the adult eel stage but no insulin was detected in the gut at any stage. No physiological or developmental significance was attributed to either the distribution or timing of expression of these peptides.

In the study of premetamorphic development of the 


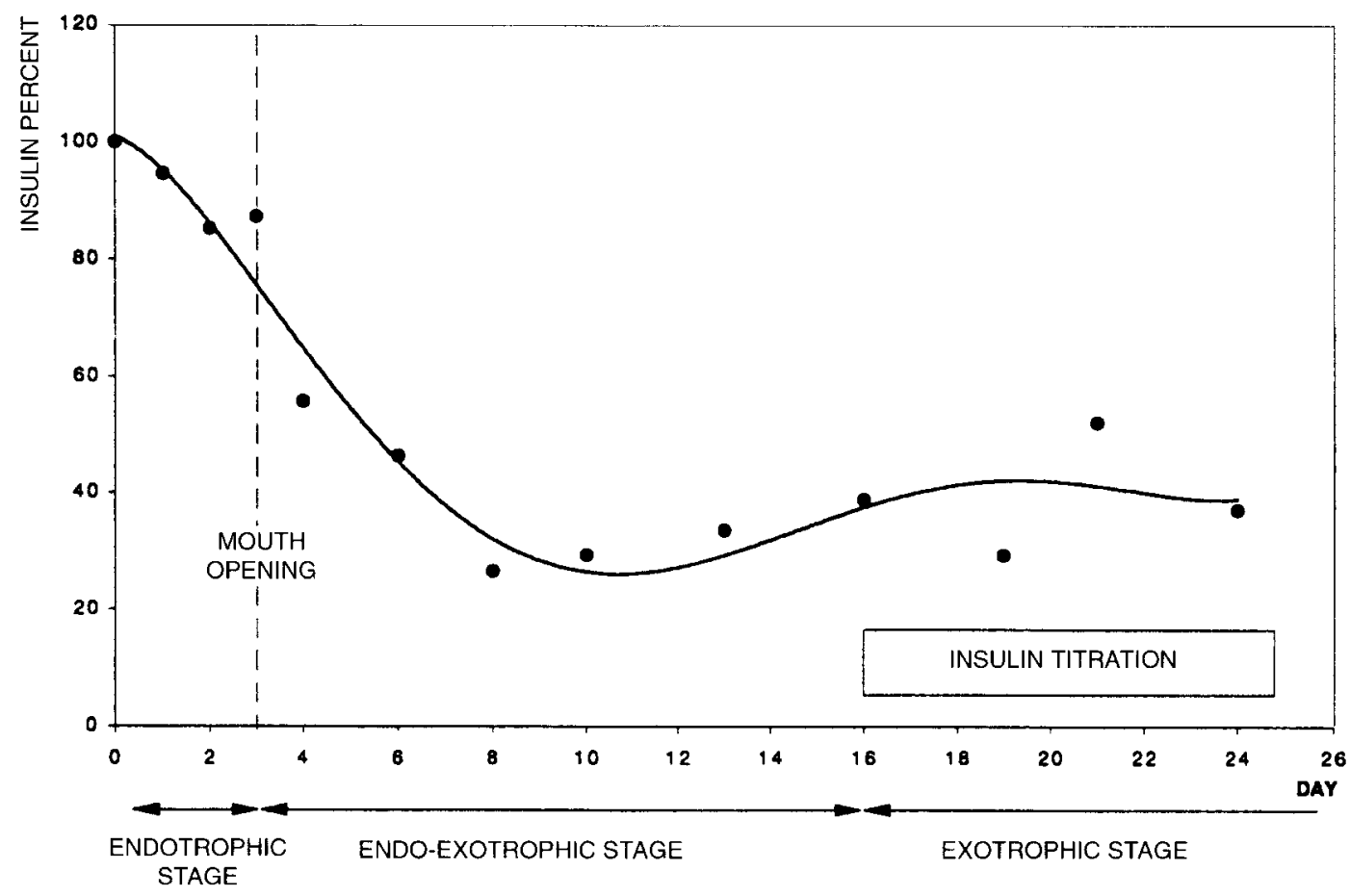

FIG. 8. A comparison of percent insulin levels (ELISA) in homogenized prelarvae and larva of the gilthead sea bream, S. aurata, at various times (days and nutritional status) during their development. Comparisons are made with prelarvae at hatching as 100\%. (From Guyot et al., 1998.)

turbot gastrointestinal endocrine cells, many more intervals of development were examined (Reinecke et al., 1997). Five prejuvenile stages (Segner et al., 1995) were described over 24 days of posthatching development. In the first 4 days (corresponding to endotrophism of yolk) there was no presence of any of the four islet-type hormones. Transient insulin immunoreactivity was present from days 5 to 10 in the stomach anlage and in the upper intestine. IGF-1 appeared in the upper intestine between 8 and 10 days and subsequently became a conspicuous component of the stomach and the two regions of the intestine after 11 days through to the 41-day-old juvenile. Somatostatinimmunoreactive cells also appeared at the same time in the stomach and upper intestine but were mostly found in the stomach thereafter. The two regions of the intestine showed immunolabeling for PP-family peptides at the 8- to 10-day stages but afterward the most prominent labeling was present in the upper intestine. The conclusion was that the differentiation of the various cell types is correlated with the onset or exogenous feeding by the larva and that metamorphosis is important to develop a finetuning of the nervous system for regulation of the blood flow to the intestine. The transient insulin immunoreactivity was a curious observation and was discussed in the context of it being a phylogenetic relict, i.e., like that seen in the intestinal epithelium of larval lampreys or possibly that insulin is related to protein synthesis during cell proliferation of the developing mucosal epithelial cells. Other curiosities were the significance of the IGF, the timing of appearance of glucagon and PP-family peptides, the colocalization of anti-SST-14 and -SST-25, and the lack of colocalization of glucagon and PPfamily peptides. The time of appearance of somatostatin in the stomach was coincident with the differentiation of this organ.

Differentiation of gastrointestinal endocrine cells has also been examined in a few direct developing bony fish. As noted earlier, the enteroendocrine cells of larval B. conchonius are not derived from the neural crest (Rombout et al., 1978). In the sea bass (D. labrax), 0- to 5-day posthatched larvae showed no immunoreactivity in the undifferentiated gut (García-Hernández et al., 1994b). After 9-15 days, at the commencement of exogenous feeding, cells immunoreactive to anti-NPY/ 
PYY were present in the intestine and by 25-46 days the same cells contained glucagon. At this latter time, insulin, SST-25, PP/glucagon-immunoreactive cells were present in the stomach but eventually (55-60 days) the somatostatin cells also stained positive for anti-SST-14. It was suggested that feeding induces intestinal cell differentiation and that immunoreactivity for both glucagon and insulin represent gut-specific forms of these hormones, i.e., GLP and IGF, respectively. There was a colocalization of glucagon with the PP-family peptides but glucagon and PP immunoreactivity appeared at the same time and the latter appeared before NPY/PYY and became more pronounced in the stomach; a reversal of this timing and distribution was found for the intestine.

\section{Cartilaginous Fish}

There is a paucity of information on the ontogeny of the GEP system in Chondrichthyes. The broadest description is that from six embryos of dogfish at the same stage of development, i.e., about one-half the size of newborn animals (El-Salhy, 1984). Islet-like clusters at this time contained B and D cells, with A cells present among the exocrine acini. The intestine contained abundant glucagon and a few insulin, somatostatin, and PP/PYY-immunoreactive cells; the stomach possessed only a few somatostatin-immunoreactive cells. At 4 months of development of $S$. stellaris, the differentiated intestine and the undifferentiated stomach possess glucagon and somatostatin; glucagon appears first in the gastric glands before the pyloric crypts (Tagliafierro et al., 1989b). According to the latter authors, the early appearance of these peptides, and others (for example, vasoactive intestinal peptide, Tagliafierro et al., 1988), is support for the view that regulatory peptides play a role in cell growth and differentiation. Recently, there have been extensive studies on the ontogeny of NPY within the GEP system and vitellointestinal duct (VID) of embryos of Scyliorhinus torazame (Chiba et al., 1995; Chiba, 1998). Immunoreactivity for NPY was detected in the sac-like pancreas at the earliest embryonic stage, $15 \mathrm{~mm}$ long. Subsequently, the cells increased in number and eventually formed clumps like those in adults. As with other peptides in previous studies on elasmobranch embryos, the intestinal immunoreactivity for NPY appeared before that in the stomach; however, gastro- intestinal localization followed that of the pancreas. The NPY and serotonin immunoreactivity in the VID is transitory and may indicate that this organ serves as an important endocrine organ regulating gut function in the embryo (Chiba, 1998).

\section{Agnathans}

We know very little about both embryonic and posthatched development and growth of hagfish (Gorbman, 1997). Thus, much of what can be stated about ontogeny of the EP system is based on observations from adults (Östberg, 1976). Barrington (1945) originally proposed that cells in the epithelium of the bile duct of hagfish proliferated and matured into islet follicles which eventually became isolated from the epithelium (Fig. 3c). This view was supported by observations of immunoreactivity for insulin in the epithelia of both the bile duct and the islet organ (Östberg et al., 1975, 1976). It was suggested at that time that the ontogenetic history of the insulin cells in the duct epithelium should be examined (Östberg, 1976), but such an investigation has not taken place. Somatostatin immunoreactivity has been shown in about $1 \%$ of the islet cells but the ontogeny of this cell or the many other endocrine cells of the intestine (Van Noorden, 1990) awaits investigation. Given that this is the first adult islet organ in vertebrate phylogeny such a study would seem to be very important (Youson, 1999).

The life cycle of the lamprey lends itself well for developmental investigations from the fertilized egg, through embryogenesis and a protracted free-living larval interval, metamorphosis to a juvenile, a second metamorphosis during sexual maturation, senescence, and death after spawning (Youson, 1985). There has been a recent review of the GEP system throughout much of this life cycle (Youson, 1999). Despite the fact that embryos and newly hatched larvae are readily available, there has been only cursory attention to these intervals (Youson and Cheung, 1990). A study of this nature is important in light of the fact that the larval islet organ is a one-hormone endocrine gland, the simplest among the vertebrates (see Fig. $3 \mathrm{~b}$ and earlier discussion). There is also an intimacy of the islets with clusters of cells within the intestinal epithelium and only some of these immunostain for insulin; many of the intraepithelial clusters immunostain for 
PP-family peptides (Cheung et al., 1991b). Since PPfamily peptides do not appear in the islets, this transitory immunoreactivity is reflecting a step in the differentiation of islet B cells (Fig. 3b). If this is the sequence of differentiation of larval islet tissue then it would be inconsistent with that observed in many other vertebrates, for PP-family peptides are among the last to appear (Berwert et al., 1995). It is important to extend these observations to embryonic intervals in lampreys, for peptides such as NPY have been shown to appear in embryogenesis of the elasmobranch GEP system (Chiba et al., 1995). The youngest larvae to be examined in lampreys (35 days old) already showed insulin-immunoreactive cell clumps in the intestinal epithelium and submucosal area but also in the extrahepatic common bile duct (Youson, 1999). This latter distribution is interesting because, as noted above, B cells of the hagfish islet organ originate from the bile duct epithelium and it has always been assumed that the intestinal epithelium of larvae yielded all of the islets (Barrington, 1945). Even younger larvae and/or embryos would be useful in deciphering this step in development which has both phylogenetic and ontogenetic implications. The timing of appearance of somatostatin immunoreactivity and whether glucagon appears during development should also be examined. The earliest immunoreactivity for somatostatin has been noted in a 79-day-old larva (Youson and Cheung, 1990).

A later stage of ontogeny of the EP system is observed during lamprey metamorphosis. Unlike the metamorphoses described earlier in the bony fishes, where changes in the GEP system seem to be more of a progression of events which began during larval life, the metamorphosis in lampreys involves a dramatic change in the islet organ(s) of the EP system. The progressive development of the cranial and caudal principal islets through seven stages of metamorphosis in the sea lamprey, P. marinus, has been investigated by autoradiography, routine electron microscopy, and immunologically at both the light and electron microscopic levels (Elliott and Youson, 1987; 1993a,b). The cranial pancreas arises through proliferation of the larval islet organ and continued recruitment of cells from the intestinal epithelium. The B cells of the caudal principal islet (Fig. 1d) have been traced through a transdifferentiation (dedifferentiation/redifferentia- tion) of cells of the extrahepatic and part of the intrahepatic common bile duct (Elliott and Youson, 1993b). D cells appear about the midpoint of metamorphosis but the timing of differentiation of F cells, which eventually sparsely populate the adult islet, has not been examined. An unknown but transitory cell type was identified early in development and may be the precursor cell to D and/or F cells. The method of development of the caudal principal islet in this lamprey, and other Northern Hemisphere species, is reminiscent of that occurring in the adult hagfish. However, a difference lies in the fact that in lampreys the bile duct does not persist beyond this stage of development. As noted earlier, if the bile duct is not involved in production of islet tissue during metamorphosis there is no caudal principal islet (Fig. 1e), such as in the Southern Hemisphere species (Hilliard et al., 1985; Youson and Cheung, 1990; Youson and Potter, 1993). Intrahepatic secondary islets arise through transformation of bile ductular epithelia during metamorphosis in some holarctic species and submucosal secondary islets appear anywhere along the intestine between the two principal islets (Youson et al., 1988). The submucosal secondary islets seem to form throughout adult life, including just before they spawn and die (Cheung et al., 1990; Youson and Cheung, 1990). A curiosity, which may be developmentally related, is that B cells in the cranial principal islet have a slight immunoreactivity to anti-anglerfish peptide Y (Cheung et al., 1991a). There appears to be a continual production of cells from the intestinal epithelium for the cranial principal islet and perhaps this apparent crossreactivity of antisera is actually reflecting the remnants of a common precursor for all cell types. The retention of such an ontogenetic character has been used to explain the colocalization of insulin and PYY in a lizard (Putti and Della Rossa, 1996).

There have been no studies specifically directed toward the ontogeny of the enteroendocrine cells of the lamprey EP system. No peptides of the glucagon family have been detected in the larval intestine or in the larval or adult islet organs. PP- and glucagonfamily peptides seem to colocalize in adult lamprey intestine (Cheung et al., 1991a). The time of appearance and origin of cells immunoreactive to these two families of peptides in the adult intestine are important, for in other vertebrates peptides of these families have 
been implicated, either directly or indirectly, in differentiation and growth during intestinal development (Upchurch et al., 1996).

\section{Summary of Fish GEP Ontogeny}

There have been only a few studies of the endocrine cells of both the pancreas and alimentary canal during both direct and indirect development of bony fishes. Even these few studies showed some variation in developmental sequences which likely are a further reflection of the diversity of this group of vertebrates. However, as in other vertebrates it seems that the endocrine cells are a direct product of the endoderm and/or its derivatives and not the neural crest or any part of the neuroectoderm. Ventral and dorsal anlagen or corresponding regions of the primitive gut may play a role in directing the type of islet organ that is found in each species of bony fish. The most recent ontogenetic study of a bony fish GEP system suggests that an ordered sequence of appearance of insulin, somatostatin, glucagon, and PP-family peptides in a developing islet organ is also reflecting the phylogenetic development of the vertebrate islet organ (Berwert et al., 1995). However, this sequence of peptides is not found in all species of bony fish examined thus far. Maternal insulin may play an important role during development at the endotrophic phase of some species (Guyot et al., 1998). In all species examined so far regulatory peptide localization in the intestine consistently precedes that of the stomach which differentiates near the commencement of exotrophic behavior.

Information on the development of the GEP system in cartilaginous fishes and an agnathan, the hagfish, is spotty due to the past limitations of sampling. In viviparous elasmobrachs local glucagon and somatostatin are critical in early development of the alimentary canal which has intestinal differentiation preceding the development of the stomach. There has been recent focus on NPY as being important to the early development of the GEP system of elasmobranchs (Chiba, 1998). Data on the ontogeny of the hagfish EP system is restricted to observations of adults. Lampreys may provide the best opportunity to study the ontogeny of the GEP system among fishes. Embryogenesis of the lamprey EP system results in a one-hormone islet organ in larvae. Larval life of up to 7 years duration provides the possibility of examining the continual production of islet tissue from cells in the intestine which may be ontogenetic precursors. Metamorphosis produces a cranial principal islet derived from the intestine, while in addition, in holarctic species, a caudal principal islet is derived from epithelium of the regressing common bile duct. Secondary islets are produced throughout adult life. Postmetamorphic islets are composed of three principal cell types and two of these types are appearing for the first time in lamprey islet tissue. The origin of these islet cells and of glucagon-immunoreactive cells in the intestine should be a future consideration.

Research into the ontogeny of the GEP system in fish would benefit from the use of the markers now being used in mammalian GEP systems. For instance, the role of PTP-NP is particularly interesting, for one of the forms of this protein tyrosine phosphatase appears early in midgut dorsal epithelium, prior to the formation of the pancreatic rudiment (Chiang and Flanagan, 1996). A second candidate marker is the hormone adrenomedullin, which in islet development of the rat is at some time found in all the principal cell types before permanently residing in the F cells (Martínez et al., 1998).

\section{CONCLUSION}

At the beginning of this present decade, several articles appeared which emphasized that fish are excellent model systems for studies in developmental biology, neurobiology, and endocrinology and that investigations with fish had already made major contributions to these general fields (Powers, 1989; Dickhoff et al., 1990; Gorbman, 1990). At the same time a more direct emphasis was made that experimental investigations of the endocrine pancreas of fish and its hormones are advantageous to a general understanding of vertebrate pancreatic physiology and biochemistry (Plisetskaya, 1990a,b). A retrospective view of this past decade reveals continued advancements in the areas of fish GEP morphology, physiology, and biochemistry. The present review has demonstrated and reinforced earlier views that, because of the large number and diversity of species, fish are an important component of any attempt to study the phylogenetic development of a system within the vertebrate body. The GEP 
system of only a small token of approximately 25,000 fish species have been studied. Despite this, some general phylogenetic and ontogenetic patterns in the GEP system have been revealed. The one-hormone islet organ in larval lampreys is followed by a twohormone gland in hagfish, a three-hormone gland in adult lampreys, and eventually, in almost all aquatic and terrestrial gnathostomes, to a four-hormone islet organ. The order of sequenced acquisition of hormones in the islet organs during phylogenetic development (insulin, somatostatin, glucagon, and PP) mirrors their ontogenetic developmental sequence and has lead some to revisit Haeckel's "ontogeny recapitulates phylogeny" (Berwert et al., 1995; Falkmer, 1995).

The distribution of the islet tissue with respect to its association with exocrine pancreatic tissue and to its degree of concentration has undergone considerable evolutionary pressure such that several arrangements can be found among and within the major groups of fishes. In the largest group, the Teleostei, the tendency is for the more generalized members to have a diffuse distribution of small islets within the exocrine acini, whereas the more derived members have their islet organs with one or more large principal islets with no or little exocrine acini associated. The functional significance of this apparent specialization is not known, for even the islet organ of adults of the ancient lampreys have principal islets independent of exocrine elements. There appears to be no functional relevance to the association of exocrine and endocrine tissues of the pancreas (Epple and Brinn, 1986). Therefore, one could speculate that the most derived teleosts eventually acquired, through parallel evolution and natural selection, at least a portion of the pancreas, with principal islets which were similar in general form to those present in an animal, the lamprey, with an ancient and conserved evolution. This leads to several questions for future consideration. Does the condition of the islet organ in derived teleosts suggest that the direction of evolution of the islet organ in teleosts is toward a more ancient condition? Is the more ancient condition of the islet organ the more specialized state? Does this mean that the diffuse islet organ of mammals is the least specialized state which is reflected in many of the basal ray-finned fishes, the cartilaginous fishes, and the lobed-finned fishes?

At the midpoint of this decade, several excellent reviews appeared emphasizing the contribution of the fish data, particularly on insulin, neuropeptide $\mathrm{Y}$, and glucagon, to the ontogenetic and phylogenetic histories of the vertebrate GEP system (Falkmer, 1995; Conlon, 1995; Plisetskaya, 1995; Larhammar, 1996; Plisetskaya and Mommsen, 1996). The bridge between the vertebrate GEP and the corresponding system in invertebrates, particularly the protochordates, had been shortened considerably (Falkmer, 1995) and efforts to unite the two systems phylogenetically continue today (McRory and Sherwood, 1997; Reinecke et al., 1999).

As the decade began there was general acceptance that there were no ontogenetic links between the cells of the GEP and nervous systems. Now there are even greater links established between these two systems with respect to differential expression of genes coding for members of several of families of regulatory peptides, particularly the somatostatin and the NPY/PP families. The fish literature on NPY, PP, and PYY has contributed greatly to our knowledge of the evolutionary history of the NPY / PP family of peptides (Conlon, 1995; Larhammar, 1996). As the decade terminates, NPY is demonstrated as important in early development of the GEP system in both fish and mammals (Upchurch et al., 1996; Chiba, 1998). As a result of research activity in the past 10 years on sea bass, the gilthead sea bream, the turbot, the dogfish, and the lamprey we have a much better picture of the ontogeny of the GEP system in fishes. However, if we wish to continue to present fish as models for experimental investigation of regulatory peptides or to use their principal islets as xenotransplants (Wright et al., 1998) we must increase the sample size and relate the ontogenetic events to those occurring in higher vertebrates. These studies should also include the factors which regulate the differentiation and growth of the GEP system in fish.

\section{ACKNOWLEDGMENTS}

This study was supported by Grant 5945 from the Natural Sciences and Engineering Research Council of Canada to J.H.Y. The authors thank many past graduate students for their contributions to these studies and the many comparative endocrinologists whose research activity is cited in this review. The cooperation and opinions of Drs. Robert Connes, August Epple, Sture Falkmer, Erika Plisetskaya, Manfred Reinecke, and James Wright were very much 
appreciated. J.H.Y. thanks Dr. Frank Moore for the invitation to write this review and Drs. Stacia Sower, Robert Dores, and Hiroshi Kawauchi, whose invitation to provide a presentation at a symposium, "Molecular Ancestry of Vertebrate Polypeptide Hormones and Neuropeptides" (Waseda University, Tokyo, Japan, November 2324, 1997), was the stimulus for the review.

\section{REFERENCES}

Abad, M. E., Agulleiro, B., and Rombout, J. H. W. M. (1986). An immunocytochemical and ultrastructural study of the endocrine pancreas of Sparus auratus L. (Teleostei). Gen. Comp. Endocrinol. 64, $1-12$.

Abad, M. E., Peeze Binkhorst, F. M., Elbal, M. T., and Rombout, J. H. W. M. (1987). A comparative immunocytochemical study of the gastro-entero-pancreatic (GEP) endocrine system in a stomachless and a stomach-containing teleost. Gen. Comp. Endocrinol. 66, 123-136.

Abad, M. E., Taverne-Thiele, J. J., and Rombout, H. W. M. (1988). Immunocytochemical and ultrastructural characterization of coexistence of pancreatic polypeptide and glucagon-like immunoreactivity in the pancreatic endocrine cells of Sparus auratus L. (Teleostei). Gen. Comp. Endocrinol. 70, 9-19.

Abad, M. E., García Ayala, A., Lozano, M. T., and Agulleiro, B. (1992). Somatostatin-14- and somatostatin-25-like peptides in pancreatic endocrine cells of Sparus aurataus (Teleost): A light and electron microscopic immunocytochemical study. Gen. Comp. Endocrinol. 86, 445-452.

Agulleiro, B., Lozano, M. T., Abad, M. E., and García Hernández, M. P. (1993). Electron-microscopic immunocytochemical study of the endocrine pancreas of sea bass (Dicentrarchus labrax). Cell Tissue Res. 274, 303-314.

Agulleiro, B., García Hernández, M. P., and Lozano, M. T. (1994). Ontogeny of the endocrine pancreas in sea bass (Dicentrarchus labrax): an ultrastructural study. II. The big and secondary islets. Cell Tissue Res. 276, 323-331.

Al-Mahrouki, A., and Youson, J. H. (1998). Immunohistochemical studies of the endocrine cells within the gastro-entero-pancreatic system of osteoglossomorpha: An ancient teleostean group. Gen. Comp. Endocrinol. 110, 125-139.

Andrew, A. (1976). An experimental investigation into the possible neural crest origin of pancreatic APUD (islet) cells. J. Embryol. Exp. Morphol. 35, 577-593.

Andrew, A. (1984). The development of the gastro-entero-pancreatic neuroendocrine system in birds. In "Evolution and Tumour Pathology of the Neuroendocrine System" (S. Falkmer, R. Hakanson, and F. Sundler, Eds.), pp. 91-109. Elsevier, Amsterdam.

Andrews, P. C., Pollock, H. G., Elliott, W. M., Youson, J. H., and Plisetskaya, E. M. (1988). Isolation and characterization of a variant somatostatin-14 and two related somatostatins of 34 and 37 residues from lamprey (Petromyzon marinus). J. Biol. Chem. 263, 15809-15814.

Baron, H. (1935). Insel-und Zymogengewebe in ihren gegenseitigen
Beziehungen bei Gasterosteus aculeatus und einigen anderen Teleeosteirn. Z. Wiss. Zool. 146, 653-665.

Barrington, E. J. W. (1945). The supposed pancreatic organs of Petromyzon fluviatilis and Myxine glutinosa. Q. J. Microsc. Sci. 85, 391-417.

Barrington, E. J. W. (1972). The pancreas and intestine. In "The Biology of Lampreys" (M. W. Hardisty and I. C. Potter, Eds.), Vol. 2, pp. 135-169. Academic Press, London.

Beccaria, C., Diaz, J.-P., Gabrion, J., and Connes, R. (1990). Maturation of the endocrine pancreas in the sea bass, Dicentrarchus labrax L. (Teleostei): An immunocytochemical and ultrastructural study. I. Glucagon-producing cells. Gen. Comp. Endocrinol. 78, 80-92.

Berwert, L., Segner, H., and Reinecke, M. (1995). Ontogeny of IGF-1 and the classical islet hormones in the turbot, Scophthalmus maximus. Peptides 16, 113-122.

Boquist, L., and Patent, G. (1971). The pancreatic islets of the teleost Scorpaena scropha: An ultrastructural study with particular regard to fibrillar granules. Z. Zellforsch. 115, 416-425.

Bonner-Weir, S., and Weir, G. C. (1979). The organization of the endocrine pancreas: A hypothetical unifying view of the phylogenetic differences. Gen. Comp. Endocrinol. 38, 28-37.

Brinn, J. E., Jr. (1973). The pancreatic islets of bony fishes. Am. Zool. 13, 653-665.

Brinn, J. E., Jr. (1975). The pancreatic islet cytology of Ictaluridae (Teleostei). Cell Tissue Res. 162, 357-365.

Carrillo, M., Zanuy, S., Duve, H., and Thorpe, A. (1986). Identification of hormone-producing cells of the endocrine pancreas of the sea bass, Dicentrarchus labrax, by ultrastructural immunocytochemistry. Gen. Comp. Endocrinol. 61, 287-301.

Chan, S. J., Cao, Q.-P., and Steiner, D. F. (1990). Evolution of the insulin superfamily: Cloning of a hybrid insulin/insulin-like growth factor cDNA from Amphioxus. Proc. Natl. Acad. Sci. USA 87, 9319-9323.

Cheung, R., Plisetskaya, E. M., and Youson, J. H. (1990). Distribution of two forms of somatostatin in the brain, anterior intestine and pancreas of adult lampreys, Petromyzon marinus. Cell Tissue Res. 262, 283-292.

Cheung, R., Andrews, P. C., Plisetskaya, E. M., and Youson, J. H. (1991a). Immunoreactivity to peptides belonging to the pancreatic polypeptide family (NPY, aPY, PP, PYY) and to glucagon-like peptide in the endocrine pancreas and anterior intestine of adult lampreys, Petromyzon marinus: An immunohistochemical study. Gen. Comp. Endocrinol. 81, 51-63.

Cheung, R., Ferreira, L. C. G., and Youson, J. H. (1991b). Distribution of two forms of somatostatin and peptides belonging to the pancreatic polypeptide family in tissues of larval lampreys, Petromyzon marinus L.: An immunohistochemical study. Gen. Comp. Endocrinol. 82, 93-102.

Chiang, M.-K., and Flanagan, J. G. (1996). PTP-NP, a new member of the receptor protein tyrosine phosphatase family, implicated in development of nervous system and pancreatic endocrine cells. Development 122, 2239-2250.

Chiba, A. (1998). Ontogeny of serotonin-immunoreactive cells in the gut epithelium of the cloudy dogfish, Scyliorhinus torazame, with reference to coexistence of serotonin and neuropeptide Y. Gen. Comp. Endocrinol. 111, 290-298. 
Chiba, A., Honma, Y., and Oka, S. (1995). Ontogenetic development of neuropeptide Y-like immunoreactive cells in the gastroenteropancreatic endocrine system of the dogfish. Cell Tissue Res. 282, 33-40.

Cimini, V., Van Noorden, S., and Polak, J. M. (1989). Co-localization of substance $\mathrm{P}_{-}$, bombesin- and peptide histidine isoleucine (PHI)-like peptides in gut endocrine cells of the dogfish Scyliorhinus stellaris. Anat. Embryol. 179, 605-614.

Cloutier, R., and Ahlberg, P. K. (1996). Morphology, characters, and the interrelationships of basal sarcopterygians. In "Interrelationships of Fishes" (M. L. J. Stiassny, L. R. Parenti, and G. D. Johnson, Eds.), pp. 445-479. Academic Press, San Diego.

Conlon, J. M. (1995). Peptide tyrosine-tyrosine (PYY)-An evolutionary perspective. Am. Zool. 35, 466-473.

Conlon, J. M., Dfgard, E., Falkmer, S., and Thim, L. (1987). A glucagon-like peptide, structurally related to mammalian oxyntomodulin, from the pancreas of a holocephalan fish, Hydrolagus colliei. Biochem. J. 245, 851-855.

Conlon, J. M., Askensten, U., Falkmer, S., and Thim, L. (1988). Primary structures of somatostatins from the islet organ of the hagfish suggest an anomalous pathway of posttranslational processing of prosomatostatin-1. Endocrinology 122, 1855-1859.

Conlon, J. M., Bondareva, V., Rusakov, Y., Plisetskaya, E. M., Mynarcik, D. C., and Whittaker, J. (1995a). Characterization of insulin, glucagon, and somatostatin from the river lamprey, Lampetra fluviatilis. Gen. Comp. Endocrinol. 100, 96-105.

Conlon, J. M., Nielsen, P. F., Youson, J. H., and Potter, I. C. (1995b). Proinsulin and somatostatin from the islet organ of the southernhemisphere lamprey Geotria australis. Gen. Comp. Endocrinol. 100, 413-422.

Conlon, J. M., Fan, H., and Fritzsh, B. (1998). Purification and structural characterization of insulin and glucagon from the bichir Polypterus senegalis (Actinopterygii: Polypteriformes). Gen. Comp. Endocrinol. 109, 86-93.

Connes, R., and Benhalima, K. (1984). Ultrastructure de l'intestin du loup Dicentrarchus labrax L. au cours du développement larvaire. Bull. Soc. Zool. France 109, 19-33.

De Pinna, M. C. C. (1996). Teleostean monophyly. In "Interrelationships of Fishes" (M. L. J. Stiassny, L. R. Parenti, and G. D. Johnson, Eds.), pp. 147-162. Academic Press, San Diego.

Diaz, J.-P., Connes, R., Divanach, P., and Barnabe, G. (1989). Développement du foie et du pancréas du loup, Dicentrarchus labrax: I. Etude de la mise en place des organes au microscope électronique à balayage. Ann. Sci. Nat. Zool. Paris 10, 87-98.

Dickoff, W. W., Brown, C. L., Sullivan, C. V., and Bern, H. A. (1990). Fish and amphibian model for developmental endocrinology. J. Exp. Zool. Suppl. 4, 90-97.

Dubois, P. M. (1989). Ontogeny of the endocrine pancreas. Horm. Res. $32,53-60$.

Elbal, M. T., Garcia Ayala, A., and Agulleiro, B. (1991). Light and electron microscopic immunocytochemical demonstration of the coexistence of somatostatin 14- and somatostatin 25-like peptides in endocrine cells of the stomach of Sparus aurata (Teleost). Gen. Comp. Endocrinol. 84, 36-43.

Elliott, M. W., and Youson, J. H. (1987). Immunohistochemical demonstration of the development of the endocrine pancreas during metamorphosis of the sea lamprey, Petromyzon marinus L. Cell Tissue Res. 247, 351-357.

Elliott, M. W., and Youson, J. H. (1993a). Development of the adult endocrine pancreas during metamorphosis in the sea lamprey, Petromyzon marinus L. I. Light microscopy and autoradiography. Anat. Rec. 237, 259-270.

Elliott, M. W., and Youson, J. H. (1993b). Development of the adult endocrine pancreas during metamorphosis in the sea lamprey, Petromyzon marinus L. II. Electron microscopy and immunocytochemistry. Anat. Rec. 237, 271-290.

El-Salhy, M. (1984). Immunocytochemical investigation of the gastroenteropancreatic (GEP) neurohormonal peptides in the pancreas and gastrointestinal tract of the dogfish Squalus acanthias. Histochemistry 80, 193-205.

Epple, A. (1967). Further observations on amphiphil cells in the pancreatic islets. Gen. Comp. Endocrinol. 9, 137-142.

Epple, A. (1969). The endocrine pancreas. In "Fish Physiology" (W. S. Hoar and D. J. Randall, Eds.), Vol. II, pp. 275-319. Academic Press, New York.

Epple, A., and Brinn, J. E. (1975). Islet histophysiology: Evolutionary correlations. Gen. Comp. Endocrinol. 27, 320-349.

Epple, A., and Brinn, J. E. (1986). Pancreatic islets. In "Vertebrate Endocrinology: Fundamentals and Biochemical Implications" (P. K. T. Pang and M. Schreibman, Eds.), Vol. 1, pp. 279-317. Academic Press, New York.

Epple, A., and Brinn, J. E. (1987). "The Comparative Physiology of the Pancreatic Islets," p. 223. Springer-Verlag, Heidelberg.

Epple, A., and Lewis, T. L. (1973). Comparative histophysiology of the pancreatic islets. Am. Zool. 13, 567-590.

Falkmer, S. (1985a). Comparative morphology of pancreatic islets in animals. In "The Diabetic Pancreas" (B. W. Volk and E. R. Arquilla, Eds.), pp. 17-52. Plenum, New York.

Falkmer, S. (1985b). Phylogenetic aspects of the brain-gut axis, with special reference to islet hormones in invertebrates and lower vertebrates. In "Neurosecretion and the Biology of Neuropeptides" (H. Kobayashi, Ed.), pp. 317-325. Japan Sci. Soc. Press, Tokyo. [Springer-Verlag, Berlin].

Falkmer, S. (1995). Origin of the parenchymal cells of the endocrine pancreas: Some phylogenetic and ontogenetic aspects. In "Endocrine Tumors of the Pancreas: Frontiers in Gastrointestinal Research" (M. Mignon and R. T. Jensen, Eds.), Vol. 23, pp. 2-29. Karger, Basel.

Falkmer, S., and Patent, G. J. (1972). Comparative and embryological aspects of the pancreatic islets. In "Handbook of Physiology, Vol. 1, The Endocrine Pancreas" (D. F. Steiner and N. Freinkel, Eds.), pp. 1-23. Williams \& Wilkins, Baltimore.

Falkmer, S., and Van Noorden, S. (1983). Ontogeny and phylogeny of the glucagon cell. Handb. Exp. Pharmacol. 66, 81-119.

Forey, P., and Janvier, P. (1994). Evolution of the early vertebrates. Am. Sci. 82, 554-565.

Fujita, T. (1962). Über das Inselsystem des Pankreas von Chimaera monstrosa. Z. Zellforsch. 57, 487-494.

Fujita, T. (1989). Present status of paraneuron concept. Arch. Histol. Cytol. 52(Suppl.), 1-8.

García Hernández, M. P., and Agulleiro, B. (1992). Ontogeny of the 
endocrine pancreas in sea bass (Dicentrarchus labrax). An immunocytochemical study. Cell Tissue Res. 270, 339-352.

García Hernández, M. P., Lozano, M. T., and Agulleiro, B. (1994a). Ontogeny of the endocrine pancreas in sea bass (Dicentrarchus labrax): an ultrastructural study. I. The primordial cord and the primitive, single primordial islets. Cell Tissue Res. 276, 309-322.

García Hernández, M. P., Lozano, M. T., an dAgulleiro, B. (1994b). Ontogeny of some endocrine cells of the digestive tract in sea bass (Dicentrarchus labrax): An immunocytochemical study. Cell Tissue Res. 277, 373-383.

Gardiner, B. G. (1993). Osteichthyes: basal actinopterygians. In "The Fossil Record" (M. J. Benton, Ed.), Vol. 2, pp. 611-619. Chapman \& Hall, London.

Gardiner, B. G., Maisey, J. G., and Littlewood, D. T. J. (1996). Interrelationships of basal neopterygians. In "Interrelationships of Fishes" (M. L. J. Stiassny, L. R. Parenti, and G. D. Johnson, Eds.), pp. 117-146. Academic Press, San Diego.

Gillett, E., Cake, M. H., Potter, I. C., and Tajbakhsh, M. (1996). Compact exocrine pancreas of ammocoetes of the southern hemisphere lamprey Mordacia mordax contains a trypsin inhibitor: Putative evolutionary considerations. J. Exp. Zool. 274, 227-233.

Gómez-Visus, I., Abad, M. E., García-Hernández, M. P., and Agulleiro, B. (1996). Occurrence of somatostatin and insulin immunoreactivities cells in the stomach of sea bass (Dicentrarchus labrax L.): Light and electron microscopic studies. Gen. Comp. Endocrinol. 102, 16-27.

Gómez-Visus, I., García-Hernández, M. P., Lozano, M. T., and Agulleiro, B. (1998). Glucagon- and NPY-related peptide-immunoreactive cells in the gut of sea bass (Dicentrarchus labrax L.): A light and electron microscopic study. Gen. Comp. Endocrinol. 112, 26-37.

Gorbman, A. (1990). Cyclostome models for speculation on evolution of vertebrate endocrine systems. J. Exp. Zool. Suppl. 4, 137-141.

Gorbman, A. (1997). Hagfish development. Zool. Sci. 14, 375-390.

Gould, S. J. (1977). “Ontogeny and Phylogeny.” Belknap-Harvard Univ. Press, Cambridge, MA.

Grande, L., and Bemis, W. E. (1996). Interrelationships of Acipenseriformes with comments on "Chondrostei." In "Interrelationships of Fishes" (M. L. J. Stiassny, L. R. Parenti, and G. D. Johnson, Eds.), pp. 85-115. Academic Press, San Diego.

Groff, K. E., and Youson, J. H. (1997). An immunohistochemical study of the endocrine cells within the pancreas, intestine and stomach of the gar (Lepisosteus osseus). Gen. Comp. Endocrinol. 106, $1-16$.

Groff, K. E., and Youson, J. H. (1998). Fine structure and immunocytochemistry of cells within the endocrine pancreas of the gar (Lepisosteus osseus). Can. J. Zool. 76, 6-18.

Grossner, D. (1968). Das Inselorgan des Crossopterygiers Latimeria chalumnae J. L. B. Smith. Z. Zellforsch. 84, 417-428.

Guyot, E., Diaz, J. P., and Connes, R. (1995). Organogenesis of liver in sea bream, Sparus aurata: J. Fish Biol. 47, 427-437.

Guyot, E., Diaz, J. P., Romestand, B., and Connes, R. (1998). Insulin during the early postembryonic development of the gilt-head sea bream, Sparus aurata: Ultrastructural, immunohistochemical, and biochemical studies. Gen. Comp. Endocrinol. 110, 147-156.

Hansen, G. N., Hansen, B. L., and Jorgensen, P. N. (1987). Insulin-, glucagon- and somatostatin-like immunoreactivity in the endo- crine pancreas of the lungfish, Neoceratodus forsteri. Cell Tissue Res. 248, 181-185.

Hashimoto, T., Kawano, H., Daikoku, S., Shima, K., Taniguchi, H., and Baba, S. (1988). Transient coappearance of glucagon and insulin in the progenitor cells of the rat pancreatic islets. Anat. Embryol. 178, 489-497.

Hildebrand, M. (1995). "Analysis of Vertebrate Structure," 4th ed. Wiley, New York.

Hilliard, R. W., Epple, A., and Potter, I. C. (1985). The morphology and histology of the endocrine pancreas of the southern hemisphere lamprey, Geotria australis Gray. J. Morphol. 184, 253-261.

Irwin, D. M., Huner, O., and Youson, J. H. (1999). Lamprey proglucagon and the origin of glucagon-like peptides. Mol. Biol. Evol., [in press].

Johnson, D. E., Torrence, J. L., Elde, R. P., Bauer, G. E., Noe, B. D., and Fletcher, D. J. (1976). Immunohistochemical localization of somatostatin, insulin and glucagon in the principal islets of the anglerfish (Lophius americanus) and the channel catfish (Ictalurus punctata). Am. J. Anat. 147, 119-124.

Jollie, M. (1973). “Chordate Morphology.” Krieger, Huntington, NY. Jönsson, A.-C. (1991). Regulatory peptides in the pancreas of two species of elasmobranchs and in the Brockmann bodies of four teleost species. Cell Tissue Res. 266, 163-172.

Klein, C., and Lange, R. H. (1977). Principal cell types in the pancreatic islet of a teleost fish, Xiphophorus helleri H. Cell Tissue Res. 176, 529-551.

Klein, C., and Van Noorden, S. (1980). Pancreatic polypeptide (PP) and glucagon cells in the pancreatic islet of Xiphophorus helleri $\mathrm{H}$. (Teleostei). Correlative immunohistochemistry and electron microscopy. Cell Tissue Res. 205, 187-198.

Kobayashi, K., and Ali, S. S. (1981). Cell types of the endocrine pancreas in the shark Schliorhinus stellaris as revealed by correlative light and electron microscopy. Cell Tissue Res. 215, 475-490.

Kobayashi, K., and Takahashi, Y. (1970). Light and electron microscopic observations on the islets of Langerhans in Carassius carassius longsdorfii. Arch. Histol. Jpn. 31, 433-454.

Kobayashi, K., and Takahashi, Y. (1974). Fine structure of Langerhans' islet cells in a marine teleost Conger japonicus Bleeker. Gen. Comp. Endocrinol. 23, 1-18.

Kobayashi, K., Shibasaki, S., and Takahashi, Y. (1976). Light and electron microscopic study on the endocrine cells of the pancreas in a marine teleost Fugu rubripes rubripes. Cell Tissue Res. 174, 161-182.

Langer, M., Van Noorden, S., Polak, J. M., and Pearse, A. G. E. (1979). Peptide hormone-like immunoreactivity in the gastrointestinal tract and endocrine pancreas of eleven teleost species. Cell Tissue Res. 199, 493-508.

Larhammar, D. (1996). Evolution of neuropeptide Y, peptide YY and pancreatic polypeptide. Regul. Pept. 62, 1-11.

Lecointre, G., and Nelson, G. (1996). Clupeomorpha, sister-group of Ostariophysi. In "Interrelationships of Fishes" (M. L. J. Stiassny, L. R. Parenti, and G. D. Johnson, Eds.), pp. 193-207. Academic Press, San Diego.

Le Douarin, N. M. (1988). On the origin of pancreatic endocrine cells. Cell 52, 196-171.

Li, G.-Q., and Wilson, M. V. H. (1996). Phylogeny of Osteoglossomor- 
pha. In "Interrelationships of Fishes" (M. L. J. Stiassny, L. R. Parenti, and G. D. Johnson, Eds.), pp. 163-174. Academic Press, San Diego.

L'Hermite, A., Ferrano, R., Dubois, M. P., and Andersen, A. C. (1985). Detection of endocrine cells by immunofluorescence method in the gastroenteropancreatic system of the adult eel, glass eel, and leptocephalic larva (Anguilla anguilla L.). Gen. Comp. Endocrinol. 58, 347-359.

Lozano, M. T., Ayala, A. G., Abad, M. E., and Agulleiro, B. (1991a). Pancreatic endocrine cells in sea bass (Dicentrarchus labrax L.): I. Immunocytochemical characterization of glucagon- and PPrelated peptides. Gen. Comp. Endocrinol. 81, 187-197.

Lozano, M. T., Ayala, A. G., Abad, M. E., and Agulleiro, B. (1991b). Pancreatic endocrine cells in sea bass (Dicentrarchus labrax L.): II. Immunocytochemical study of insulin and somatostatin peptides. Gen. Comp. Endocrinol. 81, 198-206.

Maglio, M., and Putti, R. (1998). Morphological basis of the interaction between endocrine cell types in the pancreatic islets of the teleost, Blennius gattoruggine. Tissue Cell 30, 672-683.

Mazzi, B. (1976). Note sul pancreas endocrino del polipteriforme Calamoichthys calabarcius. Atti. Acad. Sci. Torino Cl. Sci. Fis., Mat. Nat. 110, 387-392.

Martinéz, A., Weaver, C., Lopéz, J., Bhathena, S. J., Elsasser, T. H., Miller, M. J., Moody, T. W., Unsworth, E. J., and Cuttitta, F. (1996). Regulation of insulin secretion and blood glucose metabolism by adrenomedullin. Endocrinology 137, 2626-2632.

Martinéz, A., Cuttitta, F., and Teitelman, G. (1998). Expression pattern for adrenomedullin during pancreatic development in the rat reveals a common precursor with other endocrine cells. Cell Tissue Res. 293, 95-100.

McCormick, N. A. (1925). The distribution and structure of the islands of Langerhans in certain fresh-water and marine fishes. Trans. R. Can. Inst. 15, 57-81.

McRory, J. E., and Sherwood, N. M. (1997). Ancient divergence of insulin and insulin-like growth factor. DNA Cell Biol. 16, 939-949.

Millot, J., and Anthony, J. (1972). Le pancréas des crossoptérygiens coelacanthidés. Z. Zellforch. 123, 215-223.

Montuenga, L. M., Martinéz, A., Miller, M. J., Unsworth, E. J., and Cuttitta, F. (1997). Expression of adrenomedullin and its receptor during embryogenesis suggests autocrine or paracrine modes of action. Endocrinology 138, 440-451.

Nakamura, M., and Yokote, M. (1971). Ultrastructural studies on the islets of Langerhans of the carp. Z. Anat. Entwicklungsgesch. 134, 61-72.

Nelson, J. S. (1994). "Fishes of the World," 3rd ed. Wiley, New York.

Noaillac-Depeyre, J., and Hollande, E. (1981). Evidence for somatostatin, gastrin and pancreatic polypeptide-like substances in the mucosa cells of the gut in fishes with and without stomach. Cell Tissue Res. 216, 193-203.

Nozaki, M., Miyata, K., Oota, Y., Gorbman, A., and Plisetskaya, E. M. (1988a). Different cellular distributions of two somatostatins in brain and pancreas of salmonids, and their associations with insulin- and glucagon-secreting cells. Gen. Comp. Endocrinol. 69, 267-280.

Nozaki, M., Miyata, K., Oota, Y., Gorbman, A., and Plisetskaya, E. M. (1988b). Colocalization of glucagon-like peptide and glucagon immunoreactivities in pancreatic islets and intestine of salmonids. Cell Tissue Res. 253, 371-375.

Östberg, Y. (1976). "The Entero-Insular Endocrine Organ in a Cyclostome, Myxine glutinosa," pp. 1-41. Medical dissertation, Department of Pathology, Umeå University, Umeå, Sweden.

Ostberg, Y., Van Noorden, S., and Pearse, A. G. E. (1975). Cytochemical, immunofluorescence and ultrastructural investigations on polypeptide hormone localization in the islet parenchyma and bile duct mucosa of a cyclostome, Myxine glutinosa. Gen. Comp. Endocrinol. 25, 274-291.

Ostberg, Y., Boquist, L., Van Noorden, S., and Pearse, A. G. E. (1976). On the origin of islet cells in a cyclostome, Myxine glutinosa. Gen. Comp. Endocrinol. 28, 228-246.

Patent, G. J., Kechele, P. O., and Tomichek Carrano, V. (1978). Nonconventional innervation of the pancreatic islets of the teleost fish, Gillichthys mirabilis. Cell Tissue Res. 191, 305-315.

Pearse, A. G. E. (1969). The cytochemistry and ultrastructure of polypeptide hormone-producing cells (the APUD series) and the embryonic, physiologic and pathologic implications of the concept. J. Histochem. Cytochem. 17, 303-313.

Pearse, A. G. E., and Polak, J. M. (1971). Neural crest origin on the endocrine polypeptide (APUD) cells of the gastrointestinal tract and pancreas. Gut 12, 783-788.

Plisetskaya, E. M. (1989a). Physiology of fish endocrine pancreas. Fish Physiol. Biochem. 7, 39-48.

Plisetskaya, E. M. (1989b). Pancreatic peptides. In "Comparative Physiology of Regulatory Peptides" (S. Holmgren, Ed.), pp. 174-202. Chapman \& Hall, London.

Plisetskaya, E. M. (1990a). Recent studies of fish pancreatic hormones: Selected topics. Zool. Sci. 7, 335-353.

Plisetskaya, E. M. (1990b). Endocrine pancreas of teleost fish: A model for interaction of islet hormones. J. Exp. Zool. Suppl. 4, 53-57.

Plisetskaya, E. M. (1995). Peptides of insulin and glucagon superfamilies in fish. Neth. J. Zool. 45, 181-188.

Plisetskaya, E. M., and Mommsen, T. P. (1996). Glucagon and glucagon-like peptides in fishes. Int. Rev. Cytol. 168, 187-257.

Plisetskaya, E. M., Andrews, P. C., Pollock, H. G., Elliott, W. M., and Youson, J. H. (1988). Isolation and structure of adult lamprey (Petromyzon marinus) insulin. Gen. Comp. Endocrinol. 69, 46-55.

Potter, I. C., and Hilliard, R. W. (1987). A proposal for the functional and phylogenetic significance of differences in the dentition of lampreys (Agnatha: Petromyzontiformes). J. Zool. 212, 713-737.

Powers, D. A. (1989). Fish as model systems. Science 246, 352-357.

Putti, R., and Della Rossa, A. (1996). Peptide YY and insulin coexist in $\beta$-granules in B cells of the Madagascan lizard, Zonosaurus laticaudatus. Gen. Comp. Endocrinol. 103, 249-256.

Rafn, S., and Wingstrand, K. G. (1981). Structure of intestine, pancreas, and spleen of the Australian lungfish, Neoceratodus forsteri (Krefft). Zool. Scripta 10, 223-239.

Rasmussen, A.-S., and Arnason, U. (1999). Molecular studies suggest that cartilaginous fishes have a terminal position in the piscine tree. Proc. Natl. Acad. Sci. USA 96, 2177-2182.

Reddy, S., and Elliott, R. B. (1988). Ontogenic development of peptide hormones in the mammalian fetal pancreas. Experientia 44, $1-9$. 
Reddy, S., Elliott, R. B., Poole, C. A., and Ross, J. M. (1997). Double-label immunofluorescence study of glutamic acid decaroxylase in the fetal and adult ovine pancreas by light and confocal microscopy: Evidence for predominant beta-cell coexpression. Gen. Comp. Endocrinol. 106, 301-309.

Reinecke, M. (1981). Immunohistochemical localization of polypeptide hormones in endocrine cells of the digestive tract of Branchiostoma lanceolatum. Cell Tissue Res. 219, 445-456.

Reinecke, M., Drakenburg, K., Falkmer, S., and Sara, V. R. (1991). Presence of IGF-1-like peptides in the neuroendocrine system of the Atlantic hagfish, Myxine glutinosa (Cyclostomata): Evidence derived by chromotography, radioimmunoassay and immunohistochemistry. Histochemistry 96, 191-196.

Reinecke, M., Drakenberg, K., Falkmer, S., and Sara, V. R. (1992). Peptides related to insulin-like growth factor 1 in the gastro-enteropancreatic system of bony and cartilaginous fish. Regul. Pep. 37, 155-165.

Reinecke, M., Betzler, D., Drakenberg, K., Falkmer, S., and Sara, V. R. (1993a). Occurrence of members of the insulin superfamily in central nervous system and digestive tract of protochordates. Histochemistry 99, 277-285.

Reinecke, M., Maake, C., Falkmer, S., and Sara, V. R. (1993b). The branching of insulin-like growth factor 1 and insulin: An immunohistochemical analysis during phylogeny. Regl. Pept. 48, 65-76.

Reinecke, M., Weimar, E., Maake, C., Drakenberg, K., Falkmer, S., and Sara, V. R. (1994). IGF-2-like peptides are present in insulin cells of the elasmobranchian endocrine pancreas: An immunohistochemical and chromatographic study. Histochemistry 102, 365371.

Reinecke, M., Muller, C., and Segner, H. (1997). An immunohistochemical analysis of the ontogeny, distribution and coexistence of 12 regulatory peptides and serotonin in endocrine cells and nerve fibers of the digestive tract of the turbot, Scophthalmus maximus (Teleostei). Anat. Embryol. 195, 87-102.

Reinecke, M., Eppler, E., David, I., and Georges, D. (1999). Immunohistochemical evidence for the presence, localization and partial coexistence of insulin, insulin-like growth factor I and relaxin in the protochordate Ciona intestinalis. Cell Tissue Res. 295, 331-338.

Renaud, C. B. (1997). Conservation status of northern hemisphere lampreys (Petromyzontidae). J. Appl. Ichthyol. 13, 143-148.

Rombout, J. H. W. H., Lamers, C. H. J., and Hanstede, J. G. (1978). Enteroendocrine APUD cells in the digestive tract of larval Barbus conchonius (Teleostei, Cyprinidae). J. Embryol. Exp. Morphol. 47, 121-135.

Rombout, J. H. W. H., Rademakers, L. H. P. M., and van Hess, J. P. (1979). Pancreatic endocrine cells of Barbus conchonius (Teleostei, Cyprinidae). Cell Tissue Res. 203, 9-23.

Rombout, J. H. W. H., and Taverne-Thiele, J. J. (1982). An immunocytochemical and electron-microscopical study of endocrine cells in the gut and pancreas of a stomachless teleost fish, Barbus conchonius (Cyprinidae). Cell Tissue Res. 207, 577-593.

Romer, A. S. (1970). "The Vertebrate Body." Saunders, Philadelphia. Scheuermann, D. W., Adriaensen, D., Timmermans, J.-P., and De Groodt-Lasseel, M. H. A. (1991). Immunohistochemical localization of polypeptide hormones in pancreatic endocrine cells of a dipnoan fish, Protopterus aethiopicus. Acta Histochem. 91, 185-192.
Segner, H., Storch, V., Reinecke, M., Kloas, W., and Hanke, W. (1995). A tabular overview of organogenesis in larval turbot (Scophthalmus maximus L.). ICES mar. Sci. Symp. 201, 35-39.

Sekine, Y., and Yui, R. (1981). Immunohistochemical study of the pancreatic endocrine cells of the ray, Dasyatis akajei. Arch. Histol. Jpn. 44, 95-101.

Schaeffer, B. (1981). The xenacanth shark neurocranium, with comments of elasmobranch monophyly. Bull. Am. Mus. Nat. Hist. 169, $1-66$.

Siwe, S. A. (1926). Pancreasstudien. Morphol. Jahrb. 57, 84-307.

Smith, H. M. (1960). "Evolution of Chordate Structure. An Introduction to Comparative Anatomy." Holt, Rinehart \& Winston, New York.

Sower, S. A., Chiang, Y.-C., and Conlon, J. M. (1994). Polygenic expression of somatostatin in lamprey. Peptides 15, 151-154.

Stefan, Y., and Falkmer, S. (1980). Identification of four endocrine cell types in the pancreas of Cottus scorpius (Teleostei) by immunofluorescence and electron microscopy. Gen. Comp. Endocrinol. 42, 171-178.

Stefan, Y., Ravazzola, M., and Orci, L. (1981). Primitive islets contain two populations of cells with differing glucagon immunoreactivity. Diabetes 30, 192-195.

St-Onge, L., Sosa-Pineda, B., Chowdhury, K., Mansouri, A., and Gruss, P. (1997). Pax 6 is required for differentiation of glucagonproducing $\alpha$-cells in mouse pancreas. Nature 387, 406-409.

Strahan, R., and Maclean, J. L. (1969). A pancreas-like organ in the larva of the lamprey Mordacia mordax. Aust. J. Sci. 32, 54-55.

Tagliafierro, G., Bonini, E., Faraldi, G., Farina, L., and Rossi, G. G. (1988). Distribution and ontogeny of VIP-like immunoreactivity in the gastro-entero-pancreatic system of a cartilaginous fish Scyliorhinus stellaris. Cell Tissue Res. 253, 23-28.

Tagliafierro, G., Farina, L., Faraldi, G., Rossi, G. G., and Vacchi, M. (1989a). Distribution of somatostatin and glucagon immunoreactive cells in the gastric mucosa of some cartilaginous fishes. Gen. Comp. Endocrinol. 75, 1-9.

Tagliafierro, G., Rossi, G. G., Bonini, E., Faraldi, G., and Farina, L. (1989b). Ontogeny and differentiation of regulatory peptide- and serotonin-immunoreactivity in the gastrointestinal tract of an elasmobranch. J. Exp. Zool. Suppl. 2, 165-174.

Tagliafierro, M., Carlini, M., Faraldi, G., Morescalchi, A. M., Putti, R., Della Rossa, A., Fasulo, S., and Mauceri, A. (1996). Immunocytochemical detection of islet hormones in the digestive system of Protopterus annectens. Gen. Comp. Endocrinol. 102, 288-298.

Teitelman, G. (1990). Insulin cells of pancreas extend neurites but do not arise from the neuroectoderm. Dev. Biol. 142, 368-379.

Teitelman, G., Lee, J. K., and Alpert, S. (1987). Expression of cell type-specific markers during pancreatic development in the mouse: implications for pancreatic cell lineages. Cell Tissue Res. 250, 435-439.

Teitelman, G., Alpert, S., Polak, J. M., Martinez, A., and Hanahan, D. (1993). Precursor cells of mouse endocrine pancreas coexpress insulin, glucagon and the neuronal protein tyrosine hydroxylase and neuropeptide $\mathrm{Y}$, but not pancreatic polypeptide. Development 118, 1031-1039.

Thomas, T. B. (1940). Islet tissue in the pancreas of the elasmobranchii. Anat. Rec. 76, 1-17. 
Upchurch, B. H., Aponte, G. W., and Leiter, A. B. (1994). Expression of peptide $Y Y$ in all four islet cell types in the developing mouse pancreas suggests a common peptide YY-producing progenitor. Development 120, 245-252.

Upchurch, B. H., Fung, B. P., Rindi, G., Ronco, A., and Leiter, A. B. (1996). Peptide YY expression is an early event in colonic endocrine cell differentiation: Evidence from normal and transgenic mice. Development 122, 1157-1163.

Van Noorden, S. (1984). The neuroendocrine system in Protostomian and deuterostomian invertebrates and lower vertebrates. In "Evolution and Tumour Pathology of the Neuroendocrine System" (S. Falkmer, R. Hakanson, and F. Sundler, Eds.), pp. 8-38. Elsevier, Amsterdam.

Van Noorden, S. (1990). Gut hormones in cyclostomes. Fish Physiol. Biochem. 5, 399-408.

Vortsman, A. (1948). The development of the pancreas, the gall bladder, the ductus choledochus and the air bladder of Esox lucius. Biol. Jahrb. Belg. 15, 87-105.

Wagner, G. F., and McKeown, B. A. (1981). Immunocytochemical localization of hormone-producing cells within the pancreatic islets of the rainbow trout (Salmo gairdneri). Cell Tissue Res. 221, 181-192.

Wagner, G. F., McKeown, B. A., and Popham, D. J. (1981). The autoradiographic localization of zinc with the pancreatic islets of the rainbow trout (Salmo gairdneri). Histochemistry 72, 113-121.

Wang, Y.-Q., Plisetskaya, E., Baskin, D. G., and Gorbman, A. (1986). Immunocytochemical study of the pancreatic islets of the Pacific salmon, Oncorhynchuys kisutch. Zool. Sci. 3, 123-129.

Wang, Y., Nielsen, P. F., Youson, J. H., Potter, I. C., Lance, V. A., and Conlon, J. M. (1999a). Molecular evolution of peptide tyrosinetyrosine: primary structure of PYY from the lampreys Geotria australis and Lampetra fluviatilis, bichir, python and desert tortoise. Regul. Pept. 79, 103-108.

Wang, Y., Nielsen, P. F., Youson, J. H., Potter, I. C., and Conlon, J. M. (1999b). Multiple forms of glucagon and somatostatin isolated from the intestine of the southern-hemisphere lamprey Geotria australis. Gen. Comp. Endocrinol. 113, 274-282.

Weisel, G. F. (1972). Anatomy and histology of the digestive system of the paddlefish (Polyodon spathula). J. Morphol. 140, 243-256.

Wright, J. R., Jr., Yang, H., and Dooley, K. C. (1998). Tilapia-A source of hypoxia-resistant islet cells for encapsulation. Cell Transpl. 7, 299-307.
Yang, H., and Wright, J. R., Jr. (1995). A method for mass harvesting islets (Brockmann bodies) from teleost fish. Cell Transpl. 4, 621-628.

Yang, H., Morrison, C. M., Conlon, J. M., Laybolt, K., and Wright, J. R., Jr. (1999). Immunocytochemical characterization of the pancreatic islet cells of the Nile tilapia (Oreochromis niloticus). Gen. Comp. Endocrinol. 114, 47-56.

Youson, J. H. (1981). The alimentary canal. In "The Biology of Lampreys" (M. W. Hardisty and I. C. Potter, Eds.), Vol. 3, pp. 95-189. Academic Press, London.

Youson, J. H. (1985). Organ development and specialization in lamprey species. In "Evolutionary Biology of Primitive Fishes" ( $R$. E. Foreman, A. Gorbman, J. M. Dodd, and R. Olsson, Eds.), pp. 141-164. Pergamon, Oxford.

Youson, J. H. (1988). First metamorphosis. In "Fish Physiology" (W. Hoar and D. J. Randall, Eds.), Vol. llB, pp. 135-196. Academic Press, New York.

Youson, J. H. (1999). The agnathan enteropancreatic endocrine system: Phylogenetic and ontogenetic histories, structure, and function. [submitted for publication].

Youson, J. H., and Cheung, R. (1990). Morphogenesis of somatostatin- and insulin-secreting cells in the lamprey endocrine pancreas. Fish Physiol. Biochem. 8, 389-397.

Youson, J. H., and Elliott, W. M. (1989). Morphogenesis and distribution of the endocrine pancreas in adult lampreys. Fish Physiol. Biochem. 7, 125-131.

Youson, J. H., and Potter, I. C. (1993). An immunohistochemical study of enteropancreatic endocrine cells in larvae and juveniles of the southern hemisphere lampreys, Geotria australis and Mordacia mordax. Gen. Comp. Endocrinol. 92, 151-167.

Youson, J. H., Elliott, W. M., Beamish, R. J., and Wang, D. W. (1988). A comparison of endocrine pancreatic tissue in adults of four species of lampreys in British Columbia: A morphological and immunohistochemical study. Gen. Comp. Endocrinol. 70, 247-261.

Yui, R., Shimada, M., and Fujita, T. (1990). Immunohistochemical studies on peptide- and amine-containing endocrine cells and nerves in the gut and the rectal gland of the ratfish Chimaera monstrosa. Cell Tissue Res. 260, 193-201.

Zabel, M., Surdyk-Zasada, J., Lesisz, I., Jagoda, E., Wysocka, T., Seidel, J., and Grzeszkowiak, J. (1994). Immunocytochemical studies on pancreatic endocrine cells at early stages of development of the pig. Folia Histochem. Cytochem. 32, 181-185. 